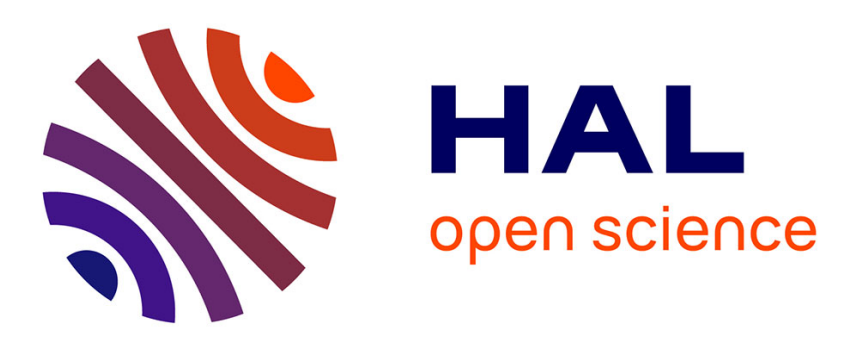

\title{
Effect of hemp content and clay stabilization on hygric and thermal properties of hemp-clay composites
}

\author{
B. Mazhoud, Florence Collet, S. Pretot, C. Lanos
}

\section{To cite this version:}

B. Mazhoud, Florence Collet, S. Pretot, C. Lanos. Effect of hemp content and clay stabilization on hygric and thermal properties of hemp-clay composites. Construction and Building Materials, 2021, 300, pp.123878. 10.1016/j.conbuildmat.2021.123878 . hal-03284301

\section{HAL Id: hal-03284301 \\ https://hal.science/hal-03284301}

Submitted on 15 Sep 2021

HAL is a multi-disciplinary open access archive for the deposit and dissemination of scientific research documents, whether they are published or not. The documents may come from teaching and research institutions in France or abroad, or from public or private research centers.
L'archive ouverte pluridisciplinaire HAL, est destinée au dépôt et à la diffusion de documents scientifiques de niveau recherche, publiés ou non, émanant des établissements d'enseignement et de recherche français ou étrangers, des laboratoires publics ou privés. 


\title{
EFFECT OF HEMP CONTENT AND CLAY STABILIZATION ON HYGRIC AND THERMAL PROPERTIES OF HEMP-CLAY COMPOSITES.
}

\author{
Brahim MAZHOUD $^{\mathrm{a}, \mathrm{b}}$, Florence COLLET ${ }^{\mathrm{a}}{ }^{*}$, Sylvie PRETOT ${ }^{\mathrm{a}}$, Christophe LANOS ${ }^{\mathrm{a}}$
}

a Univ Rennes, Laboratoire de Génie Civil et Génie Mécanique, 3 rue du Clos Courtel, 35704 Rennes, France.

${ }^{\mathrm{b}}$ present address : Université Gustave Eiffel - Laboratoire Matériaux pour Infrastructures de Transport, Campus de Nantes, Allée des ponts et chaussées, CS 5004, 44344 Bouguenais Cédex, France.

brahim.mazhoud@univ-eiffel.fr

florence.collet@univ-rennes1.fr

sylvie.pretot@univ-rennes1.fr

christophe.lanos@univ-rennes1.fr

* Corresponding author: Tel: 33.2.23.23.40.56, Fax: 33.2.23.23.40.51.

\section{Abstract}

The objective of this paper is to investigate the effect of clay stabilization and hemp content on hygric and thermal performances. This experimental study is based on the measurement of sorption isotherm, moisture buffer value and thermal properties. The effect of water content on thermal conductivity is also investigated. The results show that Hemp Clay Composites (HCC) and Hemp Stabilized Clay Composites (HSCC) are hygroscopic and moisture buffering materials. The correlations between hemp content and water content are identified for sorption curves. An innovative analysis of the contribution of hemp and binder to water sorption is performed. The moisture buffer values classify the designed composites as excellent hygric regulators according to the Nordtest classification. The thermal conductivity ranges from 0.089 to $0.120 \mathrm{~W} /(\mathrm{m} . \mathrm{K})$ at dry state, making them suitable for distributed insulation. The thermal conductivity increases linearly with density, for the two 
binders investigated in this study. Besides, the thermal conductivity increases linearly with water content too. Finally, this study underlines that the designed composites show high hygrothermal qualities.

Keywords: Hemp; clay; Sorption isotherm; Moisture buffer value; Thermal conductivity.

\section{Introduction}

In a context of sustainable development and energy saving, bio-based building materials are designed to replace conventional products in order to reduce environmental impacts. Bio-based materials are relevant because they are made from renewable raw materials and allow carbon sequestration thanks to photosynthesis during their growth [1-7]. Among them, hemp based materials have been studied extensively. Hemp concretes, generally made of hemp shiv and lime based binder, have good hygrothermal characteristics [1,5,7-16], as described below.

From a hygric point of view, hemp concretes show a high hygroscopic behavior due to the coupling of hemp shiv and binder $[1,8,9,11,12]$. It was shown that hemp concretes have sigmoid sorption curves, characteristics of macro-porous media $[8,11,17-19]$. It was also shown that the GAB model very closely fits the sorption isotherms $[9,15,16,20]$. In addition, hemp concretes have a high water vapor permeability about $10^{-11}-10^{-10}$ $\mathrm{kg} /(\mathrm{m} . \mathrm{s} . \mathrm{Pa}))[8,15-17,19,20]$. Thanks to these properties, these materials show high moisture buffering capacities with moisture buffer values globally close to or higher than $2 \mathrm{~g} /\left(\mathrm{m}^{2} . \% \mathrm{RH}\right)$, so they are classified as good or excellent hygric regulators according to the NORDTEST project $[9,15,16,20]$.

From a thermal point of view, hemp concretes have low conductivities due to their low densities. Thermal conductivities range from 0.06 to $0.19 \mathrm{~W} /(\mathrm{m} . \mathrm{K})$ for dry densities varying from 200 to $850 \mathrm{~kg} / \mathrm{m}^{3}[8,10,16,19,21-$ 27]. Cerezo gives a linear relationship between thermal conductivity and density of hemp concretes [8]. Thermal conductivity of bio-aggregate-based building materials is thus related with density. It also depends on several parameters such as formulation (binder, aggregate, aggregate to binder ratio), production method and water content. Collet and Pretot [10] reported that thermal conductivity could increase by $15-20 \%$ from dry state to $90 \%$ RH.

Life cycle assessments (LCA) carried out on hemp concrete walls including a wood frame show that hemp concrete walls have lower environmental impacts than those of walls made of usual construction materials, with 
equivalent performance $[3,4,10]$. These studies highlight the benefits of using hemp in terms of global warming potential. Indeed, bio-sourced materials are regarded as carbon sinks through photosynthesis. On the other hand, it is shown that the environmental impacts result mainly from the production phase of the raw materials and in particular from the binder production, the main contributor [5].

Thus, the use of an alternative binder can improve the environmental balance of hemp concrete while keeping satisfactory mechanical, hygric and thermal characteristics. In this context, this study aims to replace lime based binder by clay matrix. Actually, natural clay shows low environmental impacts: the resource is available in large quantities, the energy required to extract, transform and produce materials from earth is extremely low and it is a recyclable material. Compared with hemp-lime, an earth-hemp mixture is estimated to be more than 20 times less costly in grey energy $\left(49 \mathrm{MJ} / \mathrm{m}^{3}\right.$ against $\left.1166 \mathrm{MJ} / \mathrm{m}^{3}\right)$, with a carbon impact more than 5 times lower (196 $\mathrm{kgCO}_{2} / \mathrm{m}^{3}$ against $-35 \mathrm{kgCO}_{2} / \mathrm{m}^{3}$ ) [28], while leading to reduce end-of-life management costs. In addition, earth material is highly performant from a hygric point of view, due to its capacity to regulate ambient relative humidity [29]. Allinson and Hall [30] studied the hygrothermal performance of rammed earth using both experimental and numerical tools. This study concluded on the good moisture capacity of stabilized rammed earth. From a thermal point of view, earth is not a good thermal insulator due to its high density, but the coupling with bio-based aggregate should reduce the composite thermal conductivity.

Several bio-aggregates are used with earth matrix to manufacture bio-based building materials, among them: hibiscus cannabinus fibers [31,32], straw bale [33], wood [33,34], oat fibers [35], corn cob [36], millet [37], sawdust [38], coconut coir [39] or phytomass [40]. In these studies, the bio-aggregates contents are very low, inducing densities higher than $1000 \mathrm{~kg} / \mathrm{m}^{3}$ in most cases, and thus thermal conductivities higher than 0.5 $\mathrm{W} /(\mathrm{m} . \mathrm{K})$. This makes these materials unsuitable for thermal insulation purposes.

On the other hand, a few papers can be found with higher bio-aggregate contents that induce lower densities of earthen construction materials [41-46]. In these studies, thermal conductivity ranges between 0.055 and 0.18 $\mathrm{W} /(\mathrm{m} . \mathrm{K})$ for dry densities ranging from 235 to $586 \mathrm{~kg} / \mathrm{m}^{3}$. The effect of aggregate content on the thermal conductivity of composites is studied in [31,34,39,47-49]. The increase in aggregate or fiber content induces a reduction of thermal conductivity. For instance, for clay-cement-wood composites, the thermal conductivity decreases from 0.24 to $0.08 \mathrm{~W} /(\mathrm{m} . \mathrm{K})$ when the wood shavings mass content increases from 10 to $50 \%$ [47]. This variation is linked with the composite density and porosity, and a linear relationship between thermal 
conductivity $(\lambda)$ and density $(\rho)$ is defined in [47]: $\lambda=0.228 \rho-0.006$. In Bouguerra et al [50], the thermal conductivity of wood cement-clay based composites decreases from 0.439 to $0.132 \mathrm{~W} /(\mathrm{m} . \mathrm{K})$ when the wood aggregates mass content ranges from $0 \%$ to $50 \%$.

Stabilization can affect thermal conductivity of earth composites. The incorporation of pozzolan or sawdust addition in stabilized soil building blocks induces a decrease in the density and thermal conductivity while the moisture content of these materials modifies their thermal performance [51].

Lastly, the water content also impacts the thermal conductivity of composites. For rape straw clay mix and sunflower bark clay composites, the thermal conductivity increases respectively by $48.5 \%$ and by $34.5 \%$ from dry state to $98 \% \mathrm{RH}$ [44]. This increase is due to the replacement of air in the pores by water, which is a better heat conductor than air $[38,51,52]$.

Regarding the hygric properties of bio-aggregates - earth composites, the sorption isotherms show a sigmoid shape. In $[41,43]$, the mass moisture content ranges between 4.8 and $8 \%$ at $80 \% \mathrm{RH}$. The equilibrium water content increases with the plant matter content and depends on the nature of the plant, as shown in [33] for earth plasters containing wheat straw, barley straw and wood shavings.

This work investigates the use of clay as a binding matrix in hemp composites. In a previous study [53], several composites were designed using clay or stabilized clay and considering several mix proportioning regarding the intended use (floor, wall, roof). The mechanical performances of the designed composites were assessed. The present work focuses on hygric and thermal performances of these composites. The characterization is based on the measurement of the sorption isotherm, the moisture buffer value and the thermal conductivity. The impact of clay stabilization and hemp content on these hygric and thermal properties is highlighted. Then, due to the high hygroscopic capacity of these materials, the effect of water content on thermal conductivity is investigated. The investigations include experimental measurements and self-consistent scheme modelling.

\section{Materials and methods}

\subsection{Clay}


The clay was used as a binding matrix in two ways: as it is or stabilized. In this study, the term "binder" refers to "binding matrix".

The clay was the sludge from the rinsing bath of the gravel production site of Vaurifier in France. The sludge was first decanted, then dried at $100^{\circ} \mathrm{C}$, milled with a knife mill, and finally sieved with a square mesh of $2 \mathrm{~mm}$ (Fig. 1). Fig. 2 gives the particle-size distribution curve and Table 1 summarizes the main physical characteristics. All the particles are smaller than $80 \mu \mathrm{m}$, in line with the gravel production process. This material is mainly composed of silt with a medium particle size of $9.7 \mu \mathrm{m}$. The Atterberg liquid limit is medium. The chemical composition of studied clay and its X-Ray diffractograph can be found in [53]. This clay is composed of quartz, muscovite and kaolinite, ranked by content order.
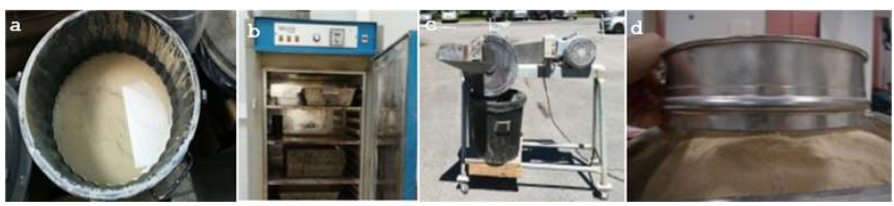

Fig. 1. Preparation of clay binder: a) decanting; b) Drying; c) Milling; d) Sieving with a square mesh of $2 \mathrm{~mm}$.

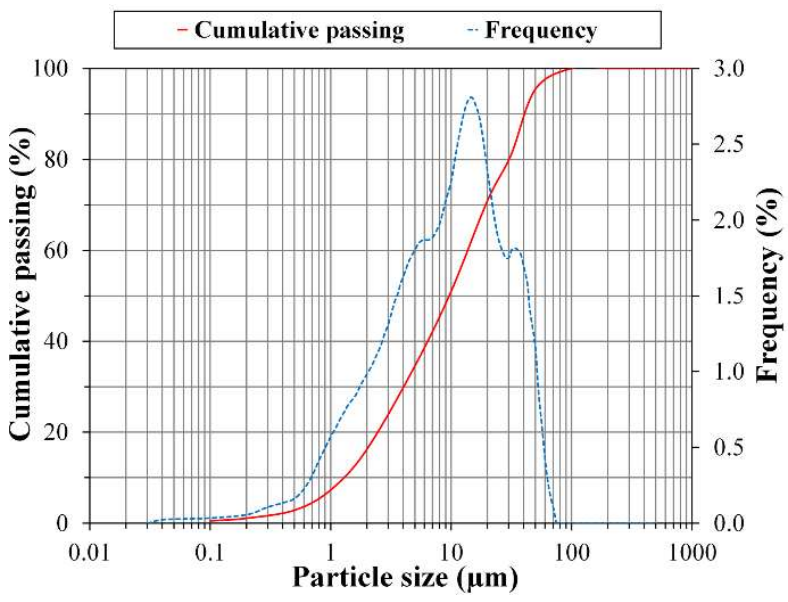

Fig. 2. Particle size distributions of clay (measured by laser technique).

Table 1. Physical characteristics of clay.

\begin{tabular}{lll}
\hline & Parameters & Clay Binder \\
\hline Density & $\rho_{\mathrm{s}}\left(\mathrm{g} / \mathrm{cm}^{3}\right)$ & 2.57 \\
\hline \multirow{2}{*}{ Atterberg limit } & Liquid Limit (LL) & 36 \\
& Plastic Limit (PL) & 26
\end{tabular}




\begin{tabular}{lll} 
& Plasticity Index (PI) & 10 \\
\hline & $\%<2 \mu \mathrm{m}$ (clay) & 14.06 \\
Grain size & $2 \mu \mathrm{m}<\%<63 \mu \mathrm{m}$ (silt) & 85.72 \\
distribution & $63 \mu \mathrm{m}<\%$ (sand) & 0.22 \\
& $\mathrm{D} 50(\mu \mathrm{m})$ & 9.7 \\
\hline
\end{tabular}

The stabilized clay was made of clay stabilized with $5 \%$ of lime-based binder (Thermo $®$ ) from BCB and $5 \%$ of Portland cement (CEM I 52.5 N CE CP2 NF) from Lafarge (Saint Pierre la cour) following the stabilization study performed in [53]. The chemical composition of these commercial binders can be found in [53].

\subsection{Shiv}

The hemp shiv used in this study was a commercial product Biofibat ${ }^{\circledR}$ (from CAVAC France). Its characteristics were obtained following the recommendations of RILEM Technical Committee 236 Bio-aggregates based Building Materials [54].

The dry bulk density of hemp shiv was about $107 \pm 3.3 \mathrm{~kg} / \mathrm{m}^{3}$. Its particle size distribution measured by mechanical sieving and by image analysis is presented in Fig. 3. Its width ranges from $0.14 \mathrm{~mm}$ to $6.8 \mathrm{~mm}$, with a medium value $\mathrm{W}_{50}$ of $2.9 \mathrm{~mm}$. The length ranges from $0.6 \mathrm{~mm}$ to $40.6 \mathrm{~mm}$, with a medium value $\mathrm{L}_{50}$ of 11.5 $\mathrm{mm}$. The equivalent diameter ranges from $0.36 \mathrm{~mm}$ to $12.48 \mathrm{~mm}$, with a medium value $\mathrm{ED}_{50}$ of $5.8 \mathrm{~mm}$.

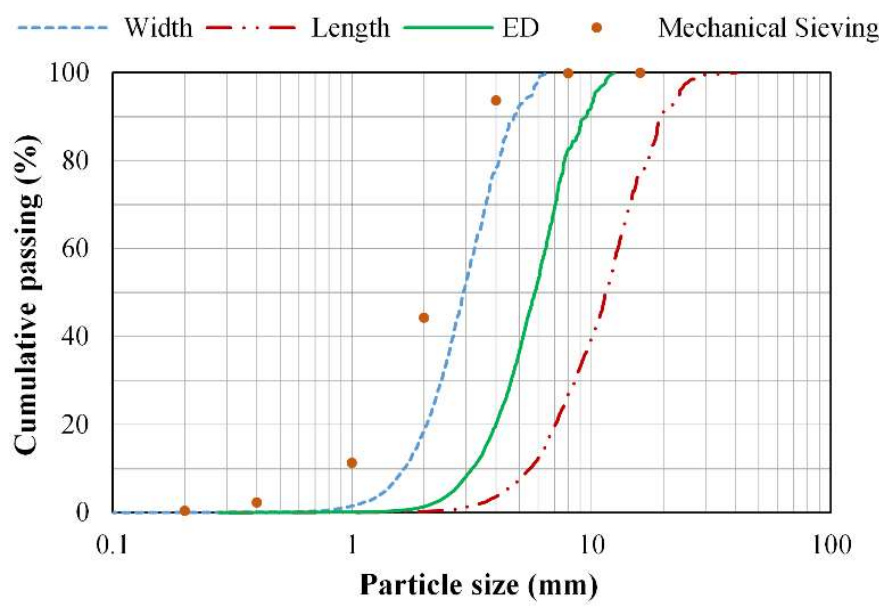

Fig. 3. Particle size distribution of shiv.

\subsection{Formulations and specimen production}


This work investigated two kinds of materials composed with the same hemp shiv and two types of binder matrix: HCC made with clay and HSCC made with stabilized clay. In order to produce materials for different applications (floor, wall and roof), four hemp to binder ratios (H/B) were considered for each kind of binder. The water demand of each binder depends on its composition. Thus, in order to reach the same mixture consistencies of the mixtures, the water content was adjusted: it was higher for stabilized clay than for clay. The different formulations are summarized in Fig. 5 and Table 2.

In order to avoid any water absorption competition between binder and hemp shiv during the mixture preparation, the binder paste was prepared separately. Firstly, dry binder and water were mixed in a mixer to form a binder paste for about $2 \mathrm{~min}$ (with water to binder mass ratio of 0.4 and 0.6 for $\mathrm{HCC}$ and HSCC respectively). At the same time, the hemp shiv was mixed separately with water by hand with water to hemp mass ratio of 0.4. Thereafter, the moist hemp was progressively added to the binder paste and mixing went on for approximately 5 min until a homogeneous mix was obtained.

The mixture was then placed in oiled cubic molds $(10 \times 10 \times 10 \mathrm{~cm})$ in 2 layers. Each layer was compacted at 0.1 MPa with a compressive testing machine leading to specimen size of about $10 \times 10 \times 7 \mathrm{~cm}$ (Fig. 4).

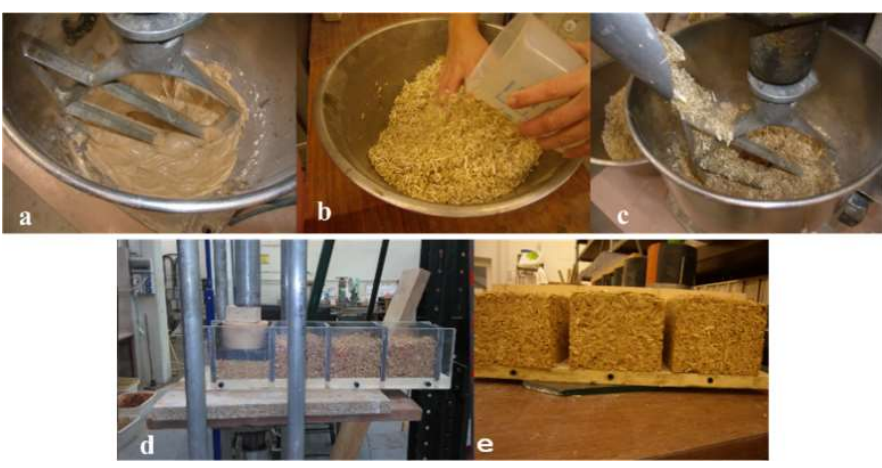

Fig. 4. Production process: a) Binder mixing (paste); b) Hemp mixing by hand; c) Addition of the moist hemp to the paste and mixing; d) Compaction; e) Designed specimens.

After manufacturing, the specimens were covered and they were stored at room temperature for a period of at least 5 days, after which the cover and the specimens were removed from the mold. Finally, the specimens were stabilized at $23{ }^{\circ} \mathrm{C}$ and $50 \%$ of relative humidity. The monitoring of mass, with daily weighing of specimens, allowed to ensure that the stabilization was reached. 

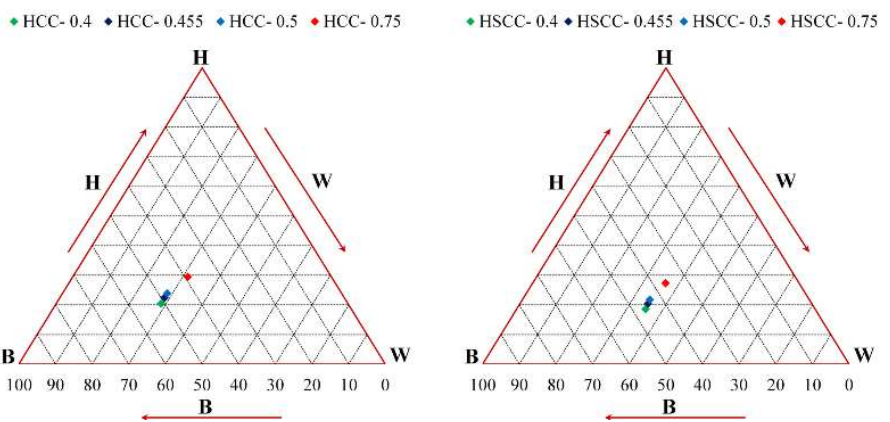

Fig. 5. Mass percentage of the components of composites (H: hemp; B: binder; W: water) - left: HCC, right:

HSCC.

Table 2. Formulation of composites: hemp to binder (H/B), water mixed with hemp to hemp $\left(\mathrm{W}_{\mathrm{H}} / \mathrm{H}\right)$, water mixed with binder to binder $\left(\mathrm{W}_{\mathrm{B}} / \mathrm{B}\right)$, and total water to binder $\left(\mathrm{W}_{\text {tot }} / \mathrm{B}\right)$ mass ratios.

\begin{tabular}{llcccc}
\hline Composite & Binder & $\mathrm{H} / \mathrm{B}$ & $\mathrm{W}_{\mathrm{H}} / \mathrm{H}$ & $\mathrm{W}_{\mathrm{B}} / \mathrm{B}$ & $\mathrm{W}_{\text {tot }} / \mathrm{B}$ \\
\hline HCC- 0.4 & Clay & 0.4 & 0.4 & 0.4 & 0.56 \\
HCC -0.455 & Clay & 0.455 & 0.4 & 0.4 & 0.58 \\
HCC -0.5 & Clay & 0.5 & 0.4 & 0.4 & 0.60 \\
HCC- 0.75 & Clay & 0.75 & 0.4 & 0.4 & 0.80 \\
\hline HSCC- 0.4 & Stabilized Clay & 0.4 & 0.4 & 0.6 & 0.76 \\
HSCC- 0.455 & Stabilized Clay & 0.455 & 0.4 & 0.6 & 0.78 \\
HSCC- 0.5 & Stabilized Clay & 0.5 & 0.4 & 0.6 & 0.80 \\
HSCC-0.75 & Stabilized Clay & 0.75 & 0.4 & 0.6 & 1.00 \\
\hline
\end{tabular}

\subsection{Densities and porosity}

The density is the ratio of the mass to the volume of the specimen. The mass was measured with an analytical balance with a readability of $0.01 \mathrm{~g}$ and a linearity of $0.01 \mathrm{~g}$. Each dimension (length, width, height) was the average of four values measured with an electronic calliper (accurate to $0.01 \mathrm{~mm}$ ). The density was measured on the four specimens of each formulation.

The skeleton density $\rho_{\mathrm{s}}$ was measured using the pycnometry method [55]. Firstly, the specimen was dried at 60 ${ }^{\circ} \mathrm{C}$ until a constant mass was reached (variation of mass lower than $0.1 \%$ between three consecutive weightings $24 \mathrm{~h}$ time-step). Then, the specimen was powderized in a blender and the powder was dried in a desiccator, at ambient temperature. Finally, the dry powder was introduced into a pycnometer of about $600 \mathrm{ml}$, immersed in toluene and regularly shaken until no bubbles could be seen. Then, the pycnometer was totally filled with toluene. Successive weightings of pycnometer, empty pycnometer $\left(\mathrm{m}_{1}\right)$, pycnometer with dry sample powder 

$\left(\mathrm{m}_{2}\right)$, pycnometer with sample powder filled with toluene $\left(\mathrm{m}_{3}\right)$, pycnometer filled with toluene $\left(\mathrm{m}_{5}\right)$ and pycnometer filled with water $\left(\mathrm{m}_{5}\right)$ led to the mass of sample and to its volume. The skeleton density was calculated with Eq.(1). Three measurements were performed for each formulation.

$\rho_{\text {s }}=\frac{m_{\text {sample }}}{V_{\text {sample }}}=\frac{m_{\text {sample }}}{V_{\text {pycno }}-V_{\text {toluene }}}=\frac{m_{2}-m_{1}}{\frac{m_{5}-m_{1}}{\rho_{\text {water }}}-\frac{m_{3}-m_{1}}{\rho_{\text {toluenne }}}}=\frac{\frac{m_{2}-m_{1}}{\frac{m_{5}-m_{1}}{\rho_{\text {water }}}-\frac{m_{3}-m_{1}}{\frac{m_{4}-m_{1}}{m_{5}-m_{1}}}}=\frac{\left(m_{4}-m_{1}\right)\left(m_{2}-m_{1}\right) \rho_{\text {water }}}{\rho_{\text {water }}}}{\left(m_{5}-m_{1}\right)\left(m_{4}-m_{1}-m_{3}+m_{2}\right)}$

The total porosity n was calculated from the skeleton density $\left(\rho_{\mathrm{s}}\right)$ and the apparent dry density $\left(\rho_{\text {app }}\right)$ of material (Eq.(2)):

$n=\frac{\rho_{s}-\rho_{a p p}}{\rho_{s}}$

\subsection{Hygric characterization}

\subsubsection{Sorption isotherm at $23^{\circ} \mathrm{C}$}

The sorption isotherm or hygroscopic curve relates the amount of equilibrium moisture content to the ambient relative humidity for a given temperature.

Sorption isotherms can be measured according to continuous or discontinuous methods [56]. In this study, the sorption isotherms were measured according to the discontinuous method: the moisture content was determined at successive stages of increasing relative humidity. The specimens were dried in an oven at $60{ }^{\circ} \mathrm{C}$ until the mass change was less than $0.1 \%$ between three consecutive weightings with $24 \mathrm{~h}$ time-step. Then, the specimens were stabilized in a climate chamber (Memmert HPP260) which regulates temperature and relative humidity. The specimens were weighed two to three times a week. The sorption isotherm was measured at $23 \pm 0.1{ }^{\circ} \mathrm{C}$. Relative humidities considered in this study were $0,35,50,65,80$ and $90 \% \mathrm{RH}$. The water content $w$ was calculated from the mass of the specimen with Eq. (3).

$w=\frac{m-m_{0}}{m_{0}}$

Where $m$ is the mass of the specimen in steady state conditions $(\mathrm{kg})$ and $m_{0}$ is the mass of the specimen in the initial dry state $(\mathrm{kg})$. 
Several models have been developed to describe the sorption curve like BET model [57,58], GAB model (4) [59-62], Van Genuchten model [63]. In this study, the selected model was the GAB one. This model relates the water content to the specific surface area of the material for multilayer sorption. Even if it is physically valid when there is no capillary condensation; the GAB model covers a wide range of relative humidity ( 5 to $80-90 \%$ $\mathrm{RH}$ ) and is convenient to fit experimental adsorption data all over the RH range. The GAB model is expressed as follows:

$\frac{w}{w_{m}}=\frac{C_{G} \cdot k \cdot \varphi}{(1-k \cdot \varphi)\left(1-k \cdot \varphi+C_{G} \cdot k \cdot \varphi\right)}$

Where $w_{m}$ is the monomolecular water content $(\mathrm{kg} / \mathrm{kg}), C_{G}$ and $k$ are the fitting parameters of the GAB model, and $\varphi$ is the relative humidity (-).

The fitting of the model to the experimental values was performed using a least-squares minimization procedure.

\subsubsection{Moisture buffer value}

The moisture buffer value MBV quantifies the moisture buffering capacity of a material. It is measured under dynamic conditions following the method defined in the NORDTEST project [64]. This value relates the amount of moisture uptake (and release), per open surface area, under daily cyclic variation of relative humidity according to equation (3). This value is mainly, but not only, a property of the material. Actually, the mass transfer coefficient at the boundary also plays a role. The control of air velocity in the surroundings of the specimens is therefore essential to be representative of conditions of use. It is checked to be around $0.1 \mathrm{~m} / \mathrm{s}$ as required in NORDTEST protocol [64].

$M B V=\frac{\Delta m}{A\left(R H_{\text {high }}-R H_{\text {low }}\right)}$

Where $M B V$ is the Moisture Buffer Value $\left(\mathrm{g} /\left(\mathrm{m}^{2} . \% \mathrm{RH}\right)\right), \Delta m$ is the moisture uptake / release during the period (g), $A$ is the open surface area $\left(\mathrm{m}^{2}\right)$ and $R H_{\text {high/low }}$ are the high/low relative humidity level (\%).

Within the NORDTEST project, a round robin test was performed on nine representative building materials. It gives initial results and leads to a classification of moisture buffer values from negligible to excellent (Fig. 6). 


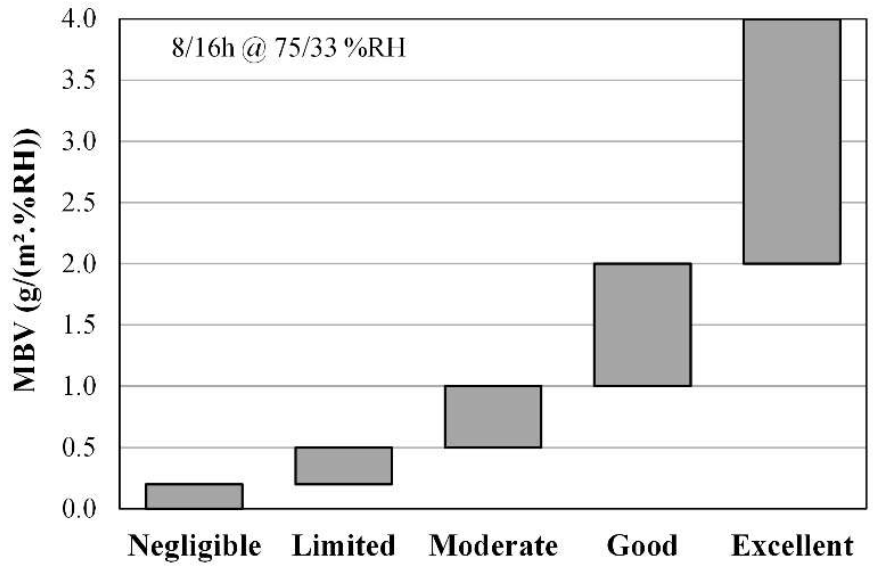

212 Fig. 6. Ranges for practical moisture buffer value classes [64].

213 The test method requires prismatic specimens sealed on five out of six sides using aluminium tape to ensure that vapor exchange only occurs through a single face of the specimen. After stabilization at $\left(23^{\circ} \mathrm{C} ; 50 \% \mathrm{RH}\right)$, specimens were exposed to daily cyclic variations: 8 hours at high relative humidity (75\%) followed by 16 hours at low relative humidity (33\%) in a climate chamber (Vötsch VC4060). The specimens were regularly weighed out of the climate chamber: five times during the absorption period and two times during the desorption period. The test continued until the change in mass $\Delta \mathrm{m}$ is the same between the last three cycles with less than $5 \%$ of discrepancies. For each specimen, the MBV was thus the average value calculated from the last 3 cycles. The MBV of the materials is the average value of the three specimens.

\subsection{Thermal conductivity}

\subsubsection{Experimental measurement}

The thermal conductivity represents the ability of a material to conduct heat under temperature gradient and steady state conditions. It quantifies how much heat flows in a material.

The measurements were performed with a transient state method using the commercial CT-meter device from SMEE with a hot wire $(5 \mathrm{~cm}$ long). The main advantage of this method, compared to steady-state methods like hot plate, is that transient methods do not induce (or limit) water migration during test [65]. Thus, they allow was as flat as possible in order to ensure good contact between the specimens and the probe. 
The measurement is based on the analysis of the temperature rise versus heating time. The heat flow and heating time were chosen to reach high enough temperature rise $\left(>10^{\circ} \mathrm{C}\right)$ and high correlation coefficient $\left(\mathrm{R}^{2}\right)$ between experimental data and theoretical curve given by Eq (4). For all formulations, the heating power and time used in this study were $0.212 \mathrm{~W}$ and $120 \mathrm{~s}$, respectively.

For all materials, two pairs were formed from four specimens. As this method leads to localized measurement, for each pair, tests were repeated at least 5 times at different places, to ensure the representativeness of the thermal conductivity values. The thermal conductivity of each pair was the average of five measurements, having a variation coefficient lower than $5 \%$. The thermal conductivity of one material was given by the average value measured on the two pairs.

$\Delta T=\frac{q}{4 \pi}(\ln (t)+K)$

Where $\mathrm{q}$ is the heat flow per meter $(\mathrm{W} / \mathrm{m})$ and $\mathrm{K}$ is a constant which takes into account the thermal diffusivity of the material.

The effect of water content on the thermal conductivity of composites was investigated for a humidity range representative of humidity met in buildings. After measurement at dry state, the test was performed at $35,50,65$ and $80 \% \mathrm{RH}$, from the lowest to the highest relative humidity. For dry state, the specimens were dried in an oven at $60{ }^{\circ} \mathrm{C}$, they were then cooled to ambient temperature in dessicator where the measurement was performed (Fig. 7). For wet state, the specimens were stabilized in a climate chamber (Memmert HPP260). For each point, the stabilization of mass was reached when the change in mass was less than $0.01 \%$ in $24 \mathrm{~h}$.

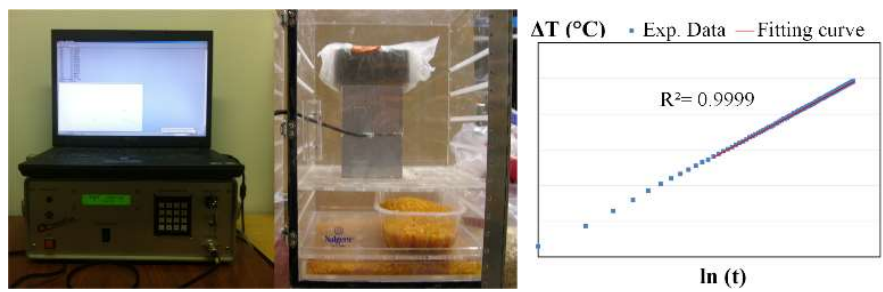

Fig. 7. Measurement of thermal conductivity at dry state - left: CT meter and dry chamber, right: experimental thermogram. 
The self-consistent scheme allows estimating the thermal conductivity of heterogeneous materials from the thermal conductivity of each component and its volume ratio. This scheme has been successfully used in several studies to model the thermal conductivity of building materials and hemp concretes $[8,10,66-68]$ considering three phases or double homogenization. The approximation of the equivalent conductivity was based on the assumption that the energy embedded in the heterogeneous medium is equivalent to that of the equivalent homogeneous medium submitted the same boundary conditions. The heterogeneous medium, with spherical inclusions, is assumed to be an assembly of composite spheres of various sizes. For a two-phase medium, a sphere of radius $R_{a}$ (phase a) is embedded in a concentric spherical shell of external radius $R_{b}$ (phase b). This composite sphere is embedded in a homogeneous and isotropic equivalent medium (Fig. 8). The equivalent thermal conductivity in this case is expressed as follows:

$\frac{\lambda_{e q}}{\lambda_{b}}=1+\frac{n}{\frac{1-n}{3}+\left(\frac{\lambda_{a}}{\lambda_{b}}-1\right)} \quad ; n=\left(\frac{R_{a}}{R_{b}}\right)^{3}$

where $\lambda_{a(r e s p, b)}$ is the thermal conductivity of the phase $a$ (resp. $\left.b\right), \mathrm{n}$ is the volume ratio of the phase a.

This method can be applied to a three-phase medium by considering an additional shell (Fig. 8). The equivalent thermal conductivity $\lambda_{\text {eq }}$ of the tricomposite homogenized medium is given by the relation (8):

$$
\frac{\lambda_{e q}}{\lambda_{c}}=1+\frac{\varepsilon}{\left[\frac{1-\varepsilon}{3}+\frac{3+\delta \times\left(\frac{\lambda_{a}}{\lambda_{b}}-1\right)}{3\left(\frac{\lambda_{a}}{\lambda_{c}}-1\right)-\delta \times\left(\frac{\lambda_{a}}{\lambda_{b}}-1\right)\left(2 \times \frac{\lambda_{b}}{\lambda_{c}}+1\right)}\right]}
$$

$\varepsilon=\left(\frac{R_{b}}{R_{c}}\right)^{3} ; \delta=1-\left(\frac{R_{a}}{R_{b}}\right)^{3}$
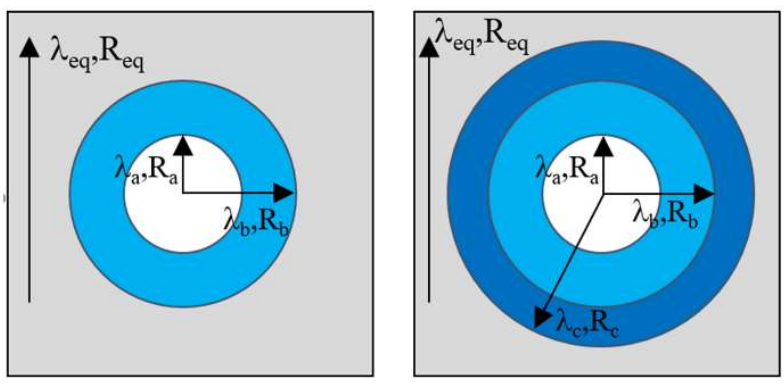

Fig. 8: Self-consistent scheme - left: two-phase composite sphere embedded in a homogeneous equivalent medium, right: three-phase composite sphere embedded in a homogeneous equivalent medium. 
In this study, the two phases model was used at dry state, considering air as phase $a$ and solid matrix (including hemp shiv and binder) as phase $b, \mathrm{n}$ was thus the porosity of the material. The three phase model was used for wet material considering air as phase $a$, water as phase $b$ and solid phase as phase $c$. $\varepsilon$ was the porosity of the material and $\delta$ was calculated from water content and porosity. Firstly, for each formulation, the experimental data at dry point were fitted with the self-consistent scheme to identify the thermal conductivity of the solid phase using the least square method. Then, the variation of thermal conductivity with water content was calculated considering the thermal conductivity of the solid phase in the three-phase model.

\section{Results and discussion}

\subsection{Density and porosity of composites}

After mass stabilization of the specimens at dry state, the density values range from $347 \mathrm{~kg} / \mathrm{m}^{3}$ to $470 \mathrm{~kg} / \mathrm{m}^{3}$ for HCC, and between $383 \mathrm{~kg} / \mathrm{m}^{3}$ and $523 \mathrm{~kg} / \mathrm{m}^{3}$ for HSCC. For a given hemp content, the density is higher with stabilized clay.

The values obtained in this study are slightly lower than the values found in previous studies for the same formulations of cylindrical specimens [53], where the density values range from $373 \mathrm{~kg} / \mathrm{m}^{3}$ to $510 \mathrm{~kg} / \mathrm{m}^{3}$ for HCC, and from $410 \mathrm{~kg} / \mathrm{m}^{3}$ to $578 \mathrm{~kg} / \mathrm{m}^{3}$ for HSCC. This slight difference can be explained by the edge effects: with cubic molds, the stacking is less compact in the corners.

Table 3 gives the apparent density at $23{ }^{\circ} \mathrm{C}$ and $50 \% \mathrm{RH}$, at dry state and the total porosity of studied materials. Fig. 9 gives the variation of the dry density of composites versus hemp content.

After mass stabilization of the specimens at dry state, the density values range from $347 \mathrm{~kg} / \mathrm{m}^{3}$ to $470 \mathrm{~kg} / \mathrm{m}^{3}$ for $\mathrm{HCC}$, and between $383 \mathrm{~kg} / \mathrm{m}^{3}$ and $523 \mathrm{~kg} / \mathrm{m}^{3}$ for HSCC. For a given hemp content, the density is higher with stabilized clay.

The values obtained in this study are slightly lower than the values found in previous studies for the same formulations of cylindrical specimens [53], where the density values range from $373 \mathrm{~kg} / \mathrm{m}^{3}$ to $510 \mathrm{~kg} / \mathrm{m}^{3}$ for HCC, and from $410 \mathrm{~kg} / \mathrm{m}^{3}$ to $578 \mathrm{~kg} / \mathrm{m}^{3}$ for HSCC. This slight difference can be explained by the edge effects: with cubic molds, the stacking is less compact in the corners. 
Table 3. Density and porosity of studied materials.

\begin{tabular}{cccccc}
\hline & $\begin{array}{c}\text { Hemp/Binder } \\
\text { ratio (H/B) }\end{array}$ & $\begin{array}{c}\text { Hemp content } \\
(\mathrm{H} /(\mathrm{H}+\mathrm{B}))\end{array}$ & $\begin{array}{c}\text { Apparent } \\
\text { density at }(23 \\
\left.{ }^{\circ} \mathrm{C} ; 50 \% \mathrm{RH}\right) \\
\left(\mathrm{kg} / \mathrm{m}^{3}\right)\end{array}$ & $\begin{array}{c}\text { Apparent } \\
\text { density at dry } \\
\text { state } \\
\left(\mathrm{kg} / \mathrm{m}^{3}\right)\end{array}$ & $\begin{array}{c}\text { Total porosity } \\
\mathrm{n}(\%)\end{array}$ \\
\hline \multirow{6}{*}{$\mathrm{HCC}$} & 0.4 & 480.2 & 469.5 & 76.1 \\
& 0.5 & 0.29 & 468.8 & 459.3 & 77.3 \\
\hline \multirow{3}{*}{ HSCC } & 0.75 & 0.31 & 420.6 & 408.0 & 78.2 \\
& 0.4 & 0.43 & 361.3 & 346.8 & 81.1 \\
\hline
\end{tabular}

The density of composite $\rho_{\text {app }}$, calculated from mix proportioning is expressed with:

$\rho_{t h}=\frac{1}{\frac{H}{\rho_{H}}+\frac{B}{\rho_{B}}} \quad$ and $\quad V_{\text {air }}=\frac{\rho_{t h}-\rho_{a p p}}{\rho_{t h}}$

then $\quad \frac{1}{\rho_{a p p}}=\left[\frac{H}{H+B}\left(\frac{1}{\rho_{H}}-\frac{1}{\rho_{B}}\right)+\frac{1}{\rho_{B}}\right]\left(1-V_{\text {air }}\right)$

Where $\rho_{\mathrm{H}}$ is the density of stacked hemp particles, $\rho_{\mathrm{B}}$ is the density of the dry binding matrix and $\mathrm{V}_{\text {air }}$ is the relative entrapped air volume.

Whatever the binding matrix, the reverse of density increases linearly with the hemp content $\mathrm{H} /(\mathrm{H}+\mathrm{B})$ according to the relationship given in Fig. 9. The density of the dry binding matrix is calculated from $\mathrm{W}_{\mathrm{B}} / \mathrm{B}(0.4$ for $\mathrm{HCC}$ and 0.6 for HSCC) and known density of clay and stabilizers. The values are $1270 \mathrm{~kg} / \mathrm{m}^{3}$ for HCC and 1020 $\mathrm{kg} / \mathrm{m}^{3}$ for HSCC. The intercept of the curves leads to the calculation of the apparent density of the entrapped air volume (297 1/ $/ \mathrm{m}^{3}$ for HCC and $407 \mathrm{l} / \mathrm{m}^{3}$ for HSCC). It appears that HSCC present more entrapped air during the production than HCC, which is not so clear analyzing the total porosity (Table 3). The slope of the curve leads to the calculation of the density of the stacked shiv particles ( $143 \mathrm{~kg} / \mathrm{m}^{3}$ for HCC and $141 \mathrm{~kg} / \mathrm{m}^{3}$ for HSCC). Interestingly, the density of shiv in the mix appears a little higher than the bulk density of dry hemp shiv but lower than the particles density evaluated by [1]: $256 \mathrm{~kg} / \mathrm{m}^{3}$. It appears that the volume affected to the particles in the mix includes voids, due to the particles entanglement. The void volume associated to the shiv particles is estimated to $45 \%$ of the apparent volume of the shiv particles in the mix (i.e. the particle volume occupied 55\% of the apparent volume of the shiv particles in the mix). 


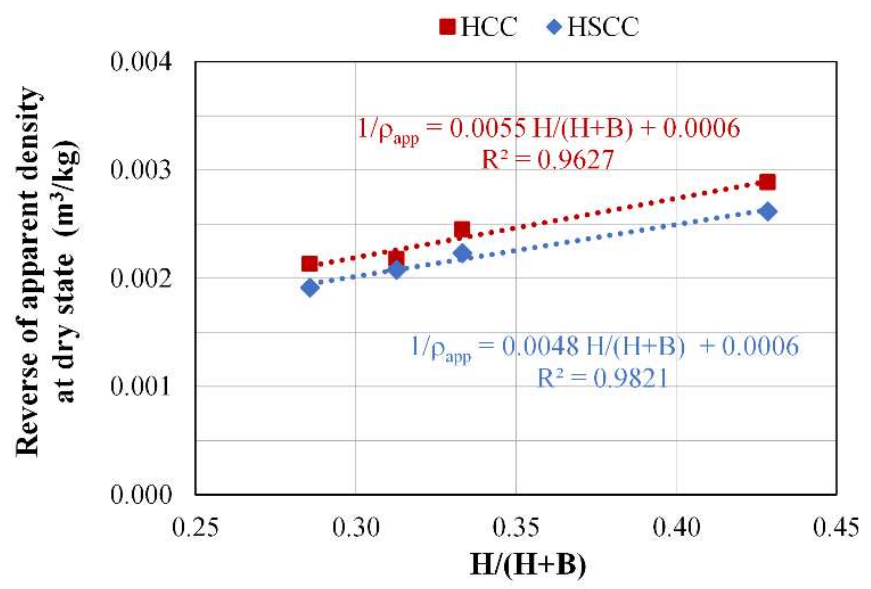

315 Fig. 9. Variation of the reverse of apparent density at dry state versus hemp to (hemp+binder) ratio.

316 Like for density, the total porosity values increase with the increase of hemp content. They range from 76 to $81 \%$ for $\mathrm{HCC}$, and from 73 to $79 \%$ for HSCC. These values are in the range of the values found in the literature for hemp-based composites $[8,10,24]$. Including data obtained for the two types of composites (Fig. 10), the total porosity of the composites decreases linearly when the apparent dry density increases with very good correlation $\left(\mathrm{R}^{2}=0.959\right)$.

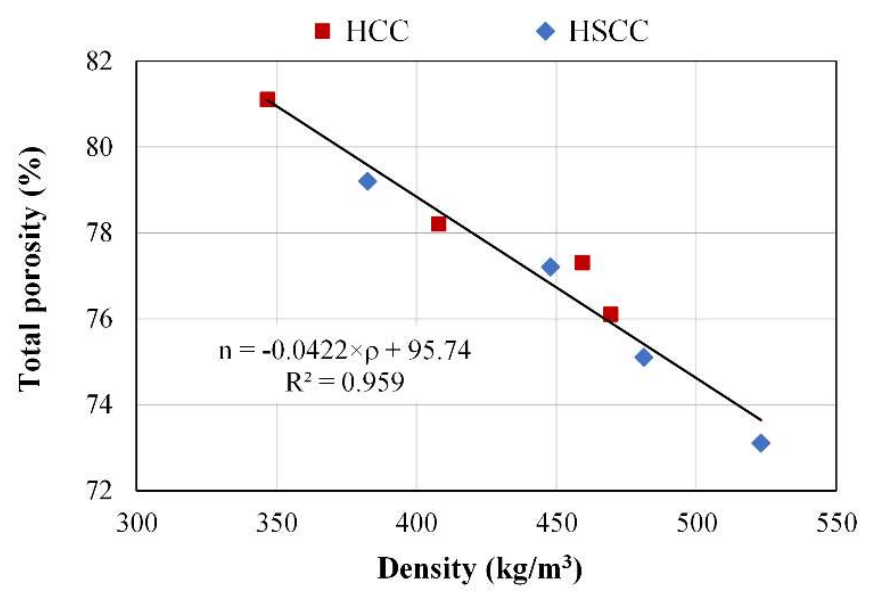

Fig. 10. Total porosity of the designed composites versus their apparent dry density.

\subsection{Hygric characterization}


Fig. 11 and Fig. 12 respectively show the adsorption isotherms obtained for hemp clay composites (HCC) and for hemp stabilized clay composites (HSCC) with different hemp to binder ratios. For HCC, the $90 \%$ RH point was not measured because of mold growth on the surface of the specimens after 48 hours of exposure to this relative humidity.

The dots correspond to the average values experimentally obtained from the mass water contents of the four specimens of a given formulation. The standard deviation values were so low that they can be considered negligible. The lines give the fittings with the GAB model. Table 4 gives the GAB model parameters obtained for the different formulations.

For all the formulations, a very good correlation between the GAB model and the experimental points is observed ( $\mathrm{R}^{2}$ very close to 1$)$. All the obtained curves are sigmoid and are classified as type II or III according to the IUPAC's classification. [56]. This is consistent with the fact that such types of curves are traditionally identified for porous media with macro pore scale.

For the range of the considered relative humidity, the water contents are slightly higher for HSCC than for HCC. Thus, for HSCC, the water contents reach $7.9 \%$ to $9.5 \%$ at $90 \% \mathrm{RH}$, and $4.6 \%$ to $6.4 \%$ at $80 \% \mathrm{RH}$. For the HCC, the water contents reach $3.9 \%$ to $5.9 \%$ at $80 \% \mathrm{RH}$. It can also be observed that the water content is also influenced by the hemp content.

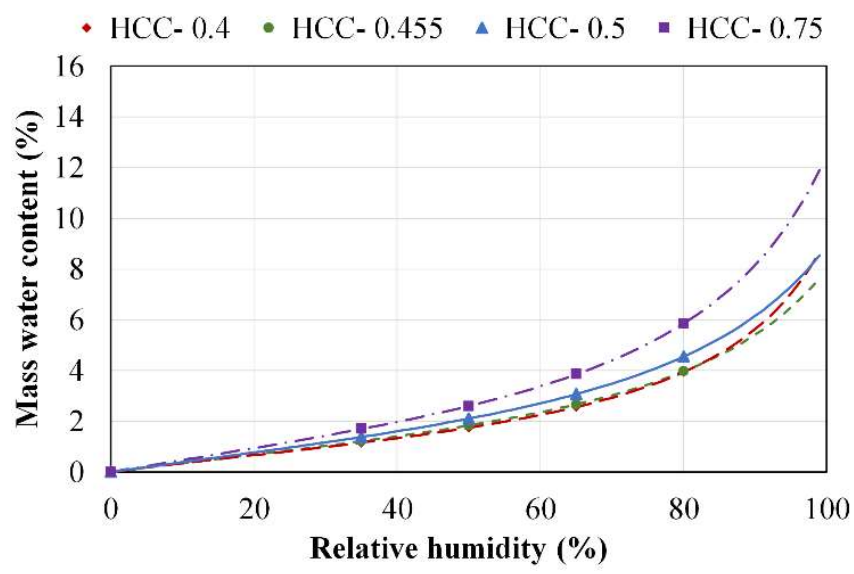


Fig. 11. Adsorption isotherm of HCC formulations (points: mean mass water content and standard deviation, lines: GAB model) for hemp to binder ratio ranging from 0.4 to 0.75 .

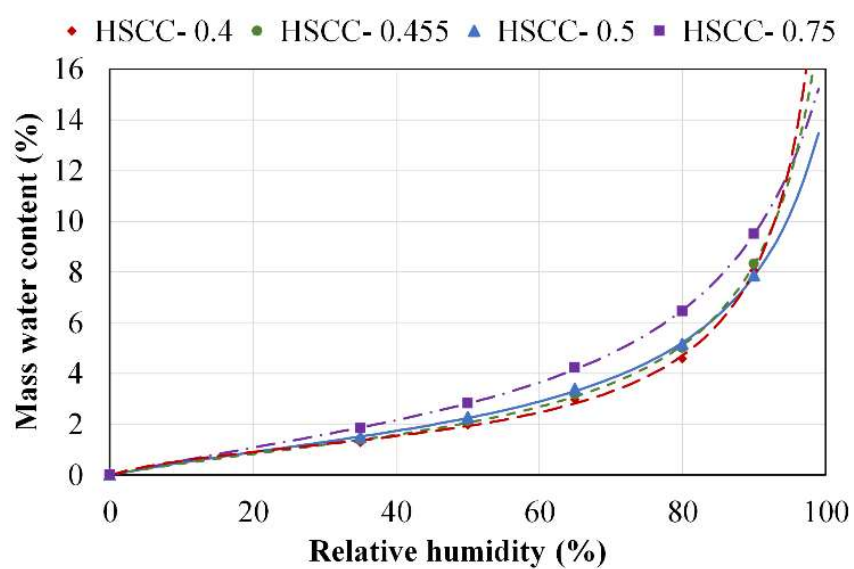

Fig. 12. Adsorption isotherm of HSCC formulations (points: mean mass water content and standard deviation, lines: GAB model) for hemp to binder ratio ranging from 0.4 to 0.75 .

Table 4. Sorption curves: Fitting parameters of GAB model (Eq.(4)) for HCC and HSCC.

\begin{tabular}{lllllll}
\hline & $\begin{array}{l}\text { Hemp/Binder } \\
\text { ratio }\end{array}$ & $\mathrm{W}_{\mathrm{m}}$ & $\begin{array}{l}\mathrm{W}_{\mathrm{m} \mathrm{Vol}} \\
\left(\mathrm{kg} / \mathrm{m}^{3}\right)\end{array}$ & $\mathrm{C}_{\mathrm{G}}$ & $\mathrm{k}$ & $\mathrm{R}^{2}$ \\
\hline \multirow{4}{*}{$\mathrm{HCC}$} & 0.4 & $1.45 \%$ & 6.81 & 3.036 & 0.851 & 1.0000 \\
& 0.455 & $1.71 \%$ & 7.85 & 2.679 & 0.804 & 1.0000 \\
& 0.5 & $2.07 \%$ & 8.45 & 2.451 & 0.790 & 1.0000 \\
& 0.75 & $2.44 \%$ & 8.46 & 2.450 & 0.821 & 1.0000 \\
\hline \multirow{4}{*}{$\mathrm{HSCC}$} & 0.4 & $1.16 \%$ & 6.07 & 7.237 & 0.953 & 0.9995 \\
& 0.455 & $1.43 \%$ & 6.88 & 3.898 & 0.928 & 0.9997 \\
& 0.5 & $1.67 \%$ & 7.48 & 3.664 & 0.889 & 0.9998 \\
& 0.75 & $2.28 \%$ & 8.72 & 3.053 & 0.866 & 0.9999 \\
\hline
\end{tabular}

The water contents obtained for the HCC and HSCC are higher than those obtained on clay bricks with a small amount of barley or wheat [69]. For unstabilized bricks, the water contents obtained with 3\% wheat in the composition are $3.6 \%$ at $80 \% \mathrm{RH}$ and $5.6 \%$ at $90 \% \mathrm{RH}$. With $3 \%$ barley in the composition, the water contents at 80 and $90 \% \mathrm{RH}$ are 3.6 and 5\%, respectively. When the bricks are stabilized with $10 \%$ cement, the water contents obtained with $3 \%$ wheat are $3.7 \%$ at $80 \% \mathrm{RH}$ and $5 \%$ to $90 \% \mathrm{RH}$ (for barley, 3 and $4 \%$ in water content respectively). The differences in water content between the HCC, the HSCC and the stabilized brick formulations in Ashour et al study [69] are attributed to the difference in bio-aggregate content, which is much lower in the Ashour et al study. 
The water contents obtained for HSCC are slightly lower than those found on clay-cement wood-aggregate composites [70]. For a wood content of $30 \%$, the water contents are about $4.2 \%$ at $65 \% \mathrm{RH}, 6.7 \%$ at $80 \% \mathrm{RH}$ and $11 \%$ at $90 \% \mathrm{RH}$. For a wood content of $40 \%$, the water contents are about $4.3 \%$ at $65 \% \mathrm{RH}, 7.8 \%$ at $80 \%$ RH and $12.9 \%$ at $90 \% \mathrm{RH}$. The higher the relative humidity, the greater the difference between the water content of HSCC and that of the clay cement wood aggregate composites.

Fig.13 and Fig. 14 show the evolution of the mass water content as a function of hemp content for HCC and HSCC respectively, for each relative humidity. Whatever the type of binder, the water content increases quite linearly with the hemp content with very good correlation coefficients. The linear regressions for each relative humidity can be used to link the mass water content of the formulations to the sorption curves of the components (binders and shiv). Assuming a direct relation between the adsorption isotherm of the composite and the adsorption isotherm of the binder and of the hemp according to their mass proportions (B: binder, $\mathrm{H}:$ hemp), the mass water content of given formulation can be calculated with Eq. (11):

$\mathrm{w}=\alpha \frac{\mathrm{H}}{H+B}+\beta \frac{\mathrm{B}}{H+B}$

Where $\mathrm{H}$ and $\mathrm{B}$ are the hemp content and the binder content, $\alpha$ and $\beta$ correspond to the adsorption isotherms of hemp and of binder respectively.

The Eq. (11) can be written as follows:

$\mathrm{w}=\mathrm{a} \frac{\mathrm{H}}{H+B}+\mathrm{b}$

With $a=\alpha-\beta$ et $b=\beta$. The parameters a and $b$ are provided by the linear regression obtained for each RH level on the Fig. 13. Then, the estimated sorption $\alpha$ and $\beta$ are evaluated.

Fig. 15 shows the identified adsorption isotherms obtained for hemp, binder of HCC and binder of HSCC in the composites. The two curves obtained for the hemp (from HCC and from HSCC) are almost superimposed, the water contents are in the range of values found in the literature [25,71].

The identified adsorption isotherm of the binder of HCC in the composite presents slightly negative values. Therefore, this binder matrix do not contribute to the sorption of the mixture. On the other hand, the identified adsorption isotherm of the binder of HSCC is positive. The obtained values are in the range of the values 

RH). experimental values obtained for all materials. Fig. 16 points out that there is very high correlation between the experimental and predicted values. In fact, it can be seen that the proposed equations provide a good prediction possible to predict, for the different studied binders, the sorption isotherms for any formulation.

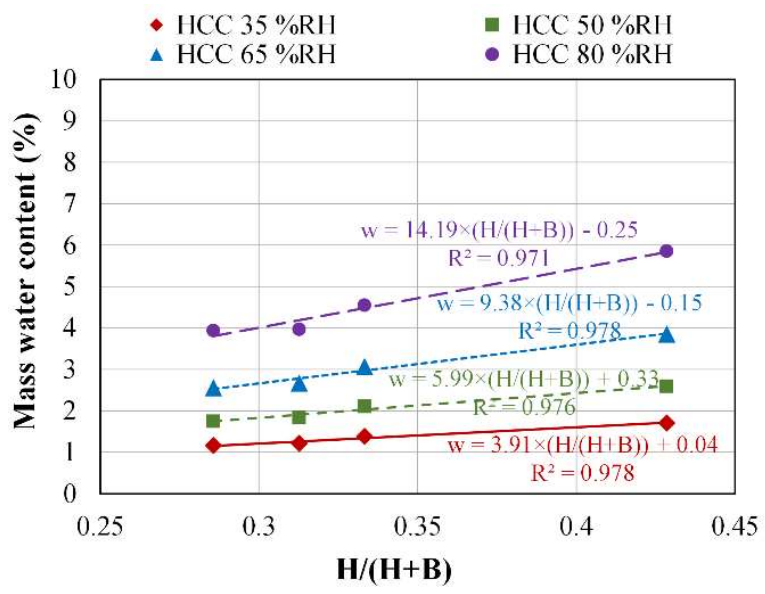
humidities.

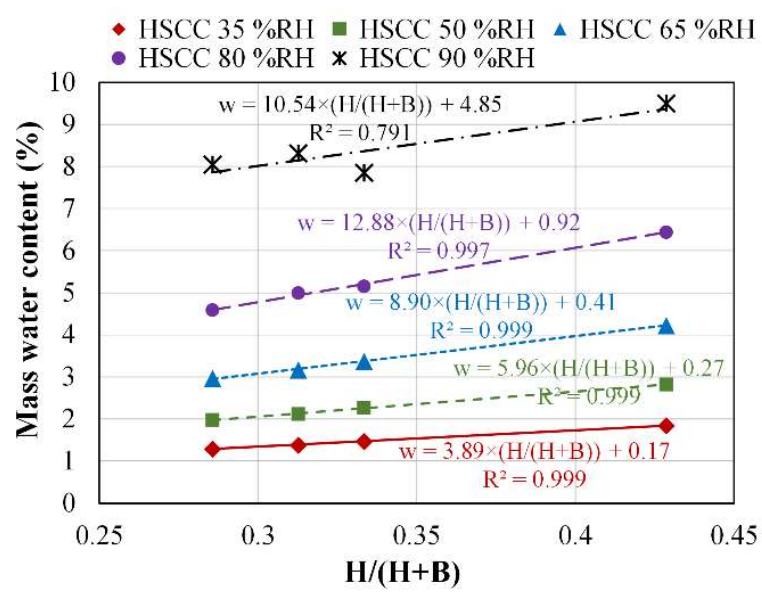

Fig. 14: Evolution of the mass water content as a function of the hemp content for HSCC under several relative humidities. 


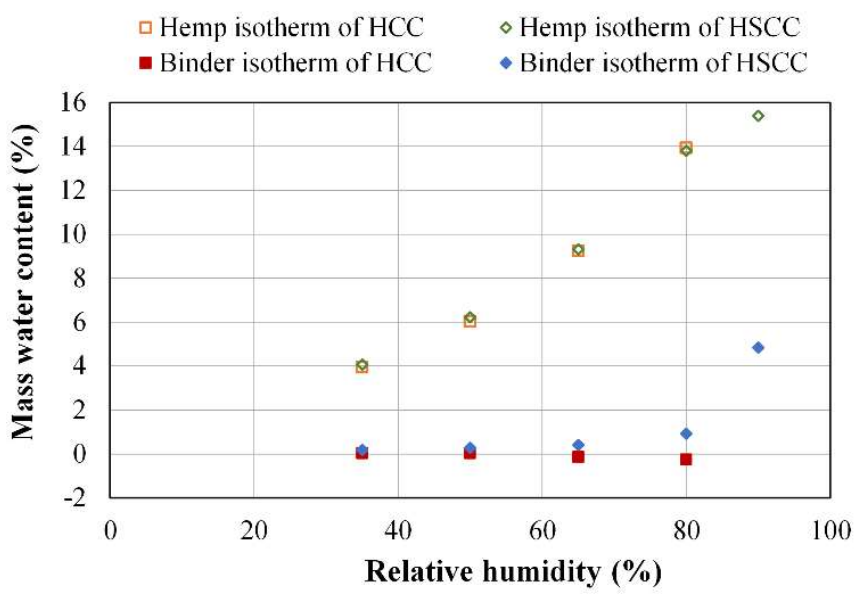

Fig. 15: Identified adsorption isotherm of hemp, binder of HCC and binder of HSCC in the composites.

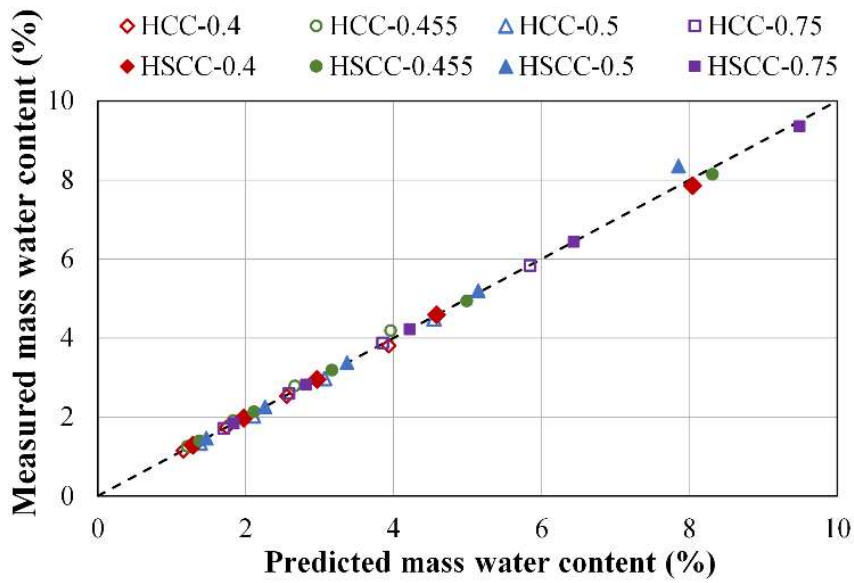

Fig. 16: Comparison between experimental and predicted values of mass water content for HCC and HSCC under several relative humidities.

\subsubsection{Moisture buffer value}

Fig. 17 shows the ambient relative humidity in the climate chamber during the test. The average value of relative humidity (RH) is slightly lower than $75 \%$ during absorption (about $71.13 \%$ ) and slightly higher than 33\% during desorption (about $35.2 \%$ ) because the door of the climatic chamber is regularly open to weigh specimens (peak on the curve). 
Fig. 17 also gives an example of moisture uptake and release during the MBV test. For all the studied materials, the measures performed on the three specimens give very close results for moisture uptake and release and thus for moisture buffer value.

The steady state is reached from the third cycle: the change in mass $\Delta \mathrm{m}$ and the moisture buffer value vary less than $5 \%$ within each cycle. Table 5 gives the average value and the standard deviation of the MBV calculated from cycles 3 to 5 in adsorption, desorption and average for all the composites. The value is very slightly higher in desorption than in adsorption.

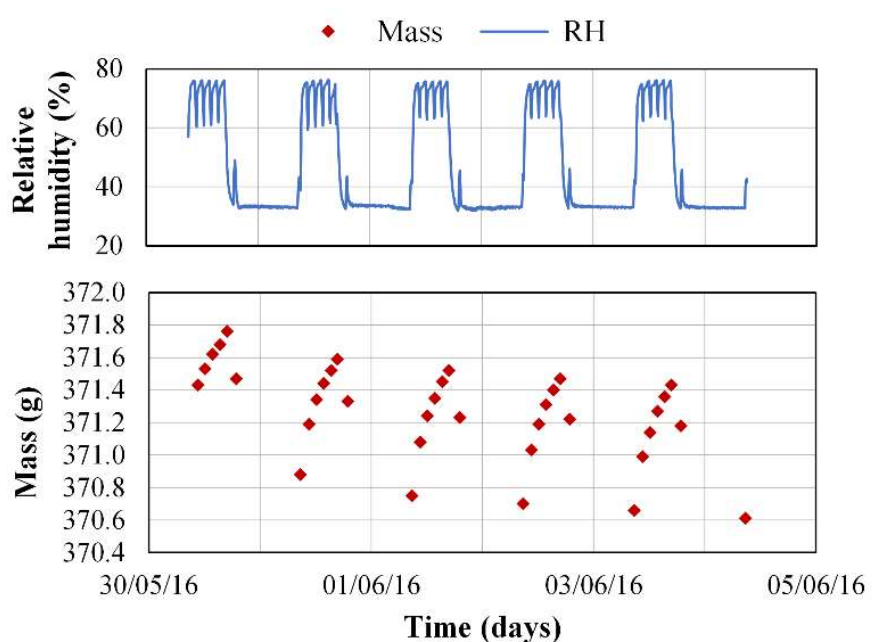

Fig. 17. Ambient relative humidity during the test and example of moisture uptake and release for one specimen of HCC-05.

Table 5. Average value and standard deviation value of Moisture Buffer Value in adsorption, desorption and average.

\begin{tabular}{llccc}
\hline & $\begin{array}{c}\text { Hemp/Binder } \\
\text { ratio }\end{array}$ & $\begin{array}{c}\text { MBV ads. } \\
\left(\mathrm{g} /\left(\mathrm{m}^{2} . \% \mathrm{RH}\right)\right)\end{array}$ & $\begin{array}{c}\text { MBV des. } \\
\left(\mathrm{g} /\left(\mathrm{m}^{2} . \% \mathrm{RH}\right)\right)\end{array}$ & $\begin{array}{c}\text { MBV av. } \\
\left(\mathrm{g} /\left(\mathrm{m}^{2} . \% \mathrm{RH}\right)\right.\end{array}$ \\
\hline \multirow{4}{*}{$\mathrm{HCC}$} & 0.4 & $1.99 \pm 0.03$ & $2.15 \pm 0.03$ & $2.07 \pm 0.03$ \\
& 0.455 & $2.05 \pm 0.02$ & $2.20 \pm 0.02$ & $2.12 \pm 0.02$ \\
& 0.5 & $2.09 \pm 0.02$ & $2.21 \pm 0.04$ & $2.15 \pm 0.03$ \\
$\mathrm{HSCC}$ & 0.75 & $2.18 \pm 0.03$ & $2.38 \pm 0.04$ & $2.28 \pm 0.03$ \\
\hline & 0.4 & $2.20 \pm 0.01$ & $2.45 \pm 0.02$ & $2.33 \pm 0.02$ \\
& 0.455 & $2.21 \pm 0.01$ & $2.42 \pm 0.02$ & $2.31 \pm 0.02$ \\
& 0.5 & $2.14 \pm 0.03$ & $2.33 \pm 0.03$ & $2.24 \pm 0.03$ \\
& 0.75 & $2.14 \pm 0.07$ & $2.43 \pm 0.07$ & $2.33 \pm 0.07$ \\
\hline
\end{tabular}

The MBV values range from 2.07 to $2.28 \mathrm{~g} /\left(\mathrm{m}^{2} . \% \mathrm{RH}\right)$ for $\mathrm{HCC}$ and from 2.24 to $2.33 \mathrm{~g} /\left(\mathrm{m}^{2} . \% \mathrm{RH}\right)$ for HSCC. According to the NORDTEST project classification, all the studied materials have an excellent moisture buffer 
capacity $\left(\mathrm{MBV}>2 \mathrm{~g} /\left(\mathrm{m}^{2} . \% \mathrm{RH}\right)\right)$. Consequently, they can be considered as excellent hygric regulators that contribute to hygrothermal comfort.

Fig. 18 shows the evolution of the moisture buffer value (MBV) of all composites as a function of density. For HCC, the MBV decreases linearly when the density increases. For HSCC, the moisture buffer value is almost constant over the studied density range.

The variation of the moisture buffer value of the composite as a function of hemp content is shown in Fig. 19. Hemp stabilized clay composite (HSCC) have higher MBV than hemp clay composite (HCC). The stabilization of clay enhances the MBV by $2-12 \%$ depending on the hemp content. composites, MBV values range from 1.94 to $2.24 \mathrm{~g} /\left(\mathrm{m}^{2} . \% \mathrm{RH}\right)[15,20,72,73]$. The MBV of HCC and HSCC are better than those obtained for Poly-Lactic Acid-based composites for which the moisture buffer value is 1.77 $\mathrm{g} /\left(\mathrm{m}^{2} . \% \mathrm{RH}\right)[72]$ and similar to those obtained for hemp-straw composites $\left(\mathrm{MBV}=2.27 \mathrm{~g} /\left(\mathrm{m}^{2} . \% \mathrm{RH}\right)\right.$ for $\rho=$ $\left.179 \mathrm{~kg} / \mathrm{m}^{3}\right)[74]$. the hemp content induces an increase in storage capacities which leads to an increase in the MBV. For HSCC, when $\mathrm{H} /(\mathrm{H}+\mathrm{B})$ increases, a compensation of storage and transfer capacities leads to constant $\mathrm{MBV}$. In order to confirm this hypothesis, complementary investigations regarding water vapor permeability could be performed.

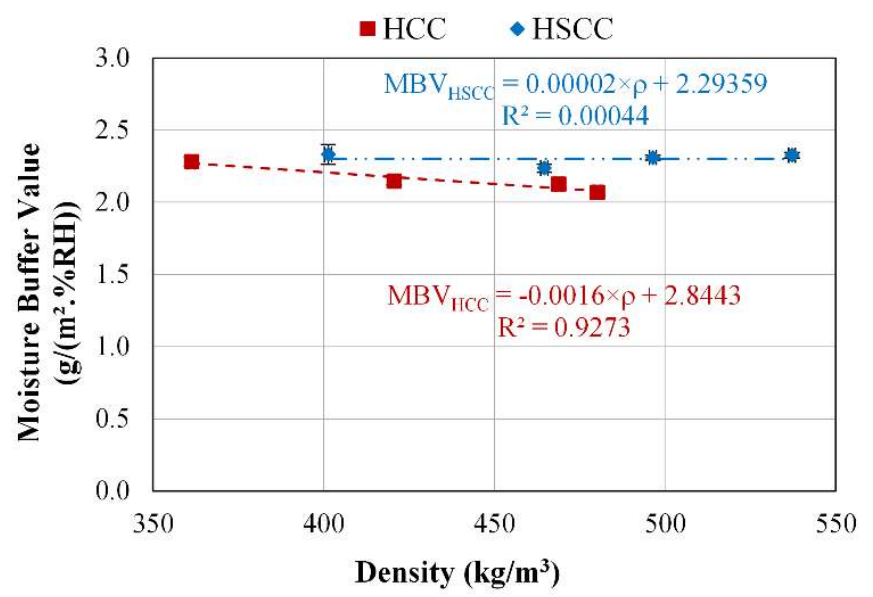




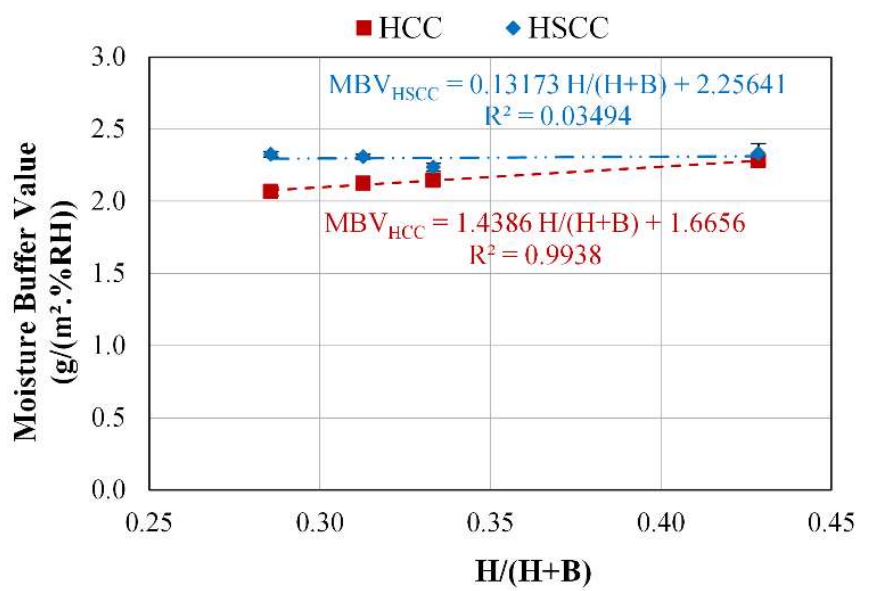

Fig. 19. Moisture Buffer Value of HCC and HSCC versus hemp content

\subsection{Thermal characterization} In comparison with the literature for hemp concrete, these thermal conductivity values are in the range of the

This section gives the experimental results and analyses regarding hemp content, stabilization of clay and water content. Then, the thermal conductivity is modelled with self-consistent scheme.

\subsubsection{Experimental results}

\subsubsection{Thermal conductivity at dry state}

Fig. 20 gives the variation of thermal conductivity versus density at dry state. For HCC, the thermal conductivity values range from 0.089 to $0.111 \mathrm{~W} /(\mathrm{m} . \mathrm{K})$ while the density values range from 346 to $470 \mathrm{~kg} / \mathrm{m}^{3}$. For HSCC, the thermal conductivity values range from 0.096 to $0.120 \mathrm{~W} /(\mathrm{m} . \mathrm{K})$ while the density values range from 382 to 523 $\mathrm{kg} / \mathrm{m}^{3}$. These thermal conductivity values make these composites suitable for distributed insulation.

The results show a linear correlation between thermal conductivity and composite density. More, for the two kinds of binder, the thermal conductivity follows the same linear relationship with density with a high correlation coefficient (Eq. (13)).

values in [8] and [21]. They are slightly lower than the values given in [24] for compacted hemp concrete and in 


\section{Linear regression of thermal conductivity versus density of hemp concrete established by Cerezo [8]:}

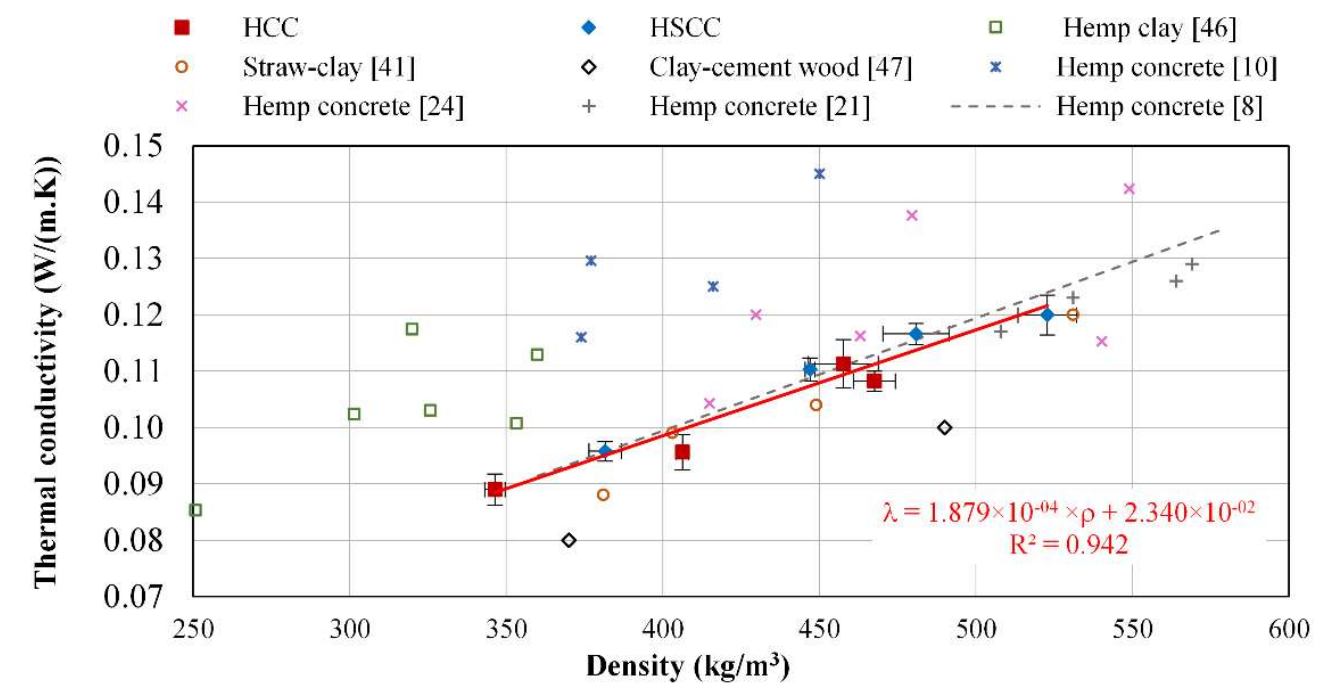

Fig. 20. Thermal conductivity of HCC and HSCC versus density at dry state. 
stabilization of clay increases the thermal conductivity by $5-15 \%$ depending on the hemp content. This is related to the higher density and lower porosity of HSCC than HCC for a given hemp content (After mass stabilization of the specimens at dry state, the density values range from $347 \mathrm{~kg} / \mathrm{m}^{3}$ to $470 \mathrm{~kg} / \mathrm{m}^{3}$ for HCC, and between 383 $\mathrm{kg} / \mathrm{m}^{3}$ and $523 \mathrm{~kg} / \mathrm{m}^{3}$ for HSCC. For a given hemp content, the density is higher with stabilized clay.

The values obtained in this study are slightly lower than the values found in previous studies for the same formulations of cylindrical specimens [53], where the density values range from $373 \mathrm{~kg} / \mathrm{m}^{3}$ to $510 \mathrm{~kg} / \mathrm{m}^{3}$ for HCC, and from $410 \mathrm{~kg} / \mathrm{m}^{3}$ to $578 \mathrm{~kg} / \mathrm{m}^{3}$ for HSCC. This slight difference can be explained by the edge effects: with cubic molds, the stacking is less compact in the corners.

Table 3).

The thermal conductivity decreases when the hemp to binder ratio increases. For HCC, the thermal conductivity decreases by $18 \%$ from 0.108 to $0.089 \mathrm{~W} /(\mathrm{m} . \mathrm{K})$ as the hemp to binder ratio increased from 0.4 to 0.75 . For HSCC the thermal conductivity decreases by $20 \%$ from 0.120 to $0.096 \mathrm{~W} /(\mathrm{m} . \mathrm{K})$ as the hemp to binder ratio rises from 0.4 to 0.75 . This result is similar to other studies performed on wood-aggregate based composites and on hemp-aggregate based composites where the increase of the bio-aggregate to binder ratio induces a decrease in the thermal conductivity of the composite $[10,19,22,47,49,70,76-78]$. Bederina et al underline that the decrease in thermal conductivity is not linearly proportional to the increase of bio-aggregate in wood-based composite [77]. Similar results are found on hemp concretes [10,22]. Actually, the decrease in thermal conductivity is linked to the decrease in density induced by the increase in bio-aggregate ratio. As the reverse of density evolves linearly with the hemp content $(\mathrm{H} /(\mathrm{H}+\mathrm{B}),-$ and the thermal conductivity evolves linearly with density, the reverse of the thermal conductivity evolves linearly with hemp content, as shown Fig. 22. The intercept of the curve and the value at $\mathrm{H} /(\mathrm{H}+\mathrm{B})=1$ leads to the determination of the porous binding matrix and shiv particles conductivity values $\left(\lambda_{\mathrm{B}}\right.$, resp. $\left.\lambda_{\mathrm{H}}\right)$ : for HCC $\lambda_{\mathrm{B}}=0.207 \mathrm{~W} /(\mathrm{m} . \mathrm{K})$ and $\lambda_{\mathrm{H}}=0.050 \mathrm{~W} /(\mathrm{m} . \mathrm{K})$ for HSCC $\lambda_{\mathrm{B}}=0.251 \mathrm{~W} /(\mathrm{m} . \mathrm{K})$ and $\lambda_{\mathrm{H}}=0.052 \mathrm{~W} /(\mathrm{m} . \mathrm{K})$. The thermal conductivity values of hemp shiv are close to the values given in [8]: 0.048 $\mathrm{W} /(\mathrm{m} . \mathrm{K})$ for bulk particles with apparent density of $110 \mathrm{~kg} / \mathrm{m}^{3}$, and $0.058 \mathrm{~W} /(\mathrm{m} . \mathrm{K})$ for bulk particles with apparent density of $155 \mathrm{~kg} / \mathrm{m}^{3}$. 


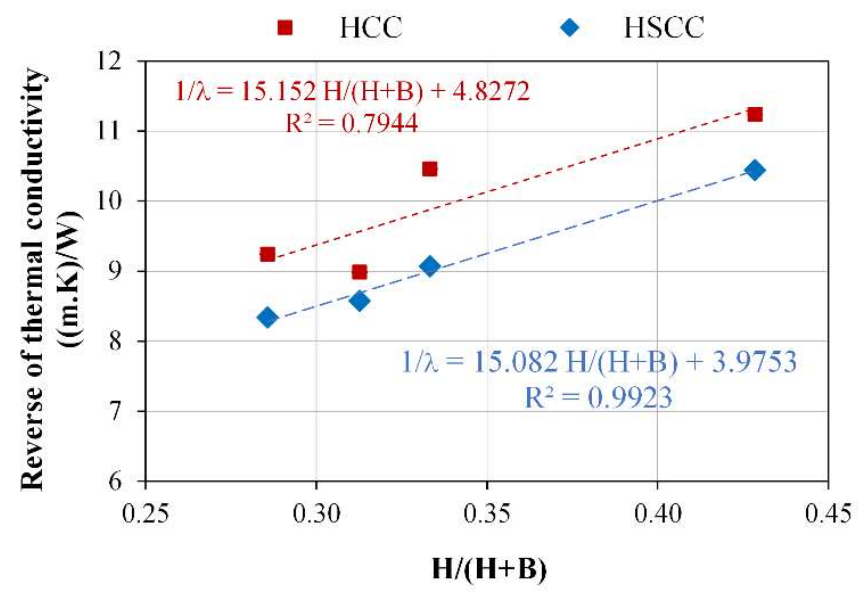

Fig. 21. Reverse of the thermal conductivity of $\mathrm{HCC}$ and $\mathrm{HSCC}$ versus $\mathrm{H} /(\mathrm{H}+\mathrm{B})$ ratio at dry state.

\subsubsection{Variation of thermal conductivity of composites with water content}

The evolution of thermal conductivity as a function of water content is given in the Fig. 22 and Fig. 23 for HCC and HSCC, respectively. Between the dry state and the $80 \%$ RH point, the thermal conductivity of HSCC increases by 14.1 to $17.5 \%$ (depending on the $\mathrm{H} / \mathrm{B}$ ratio) and by 12.3 to $16.9 \%$ for $\mathrm{HCC}$. The thermal conductivity increases linearly with the water content for all formulations, due to higher thermal conductivity for water than for air $\left(\lambda_{\text {water }}=0.6, \lambda_{\text {air }}=0.026 \mathrm{~W} /(\mathrm{m} . \mathrm{K})\right)$. Fig. 22 and Fig. 23 show also the relationships defined by fitting of the experimental points.

For both types of binder, the effect of water content on thermal conductivity is all the more important as the hemp content is low. This effect is also higher for HSCC than for $\mathrm{HCC}$, excepted for $\mathrm{H} / \mathrm{B}=0.4$ : the slope values range from 0.27 to 0.47 for HCC while they range from 0.30 to 0.43 for HSCC. As the water content obtained for a given relative humidity is slightly higher for HSCC than HCC (see section on sorption isotherms Fig. 13 and Fig. 14)), HSCC are the most affected by changes in ambient relative humidity. 


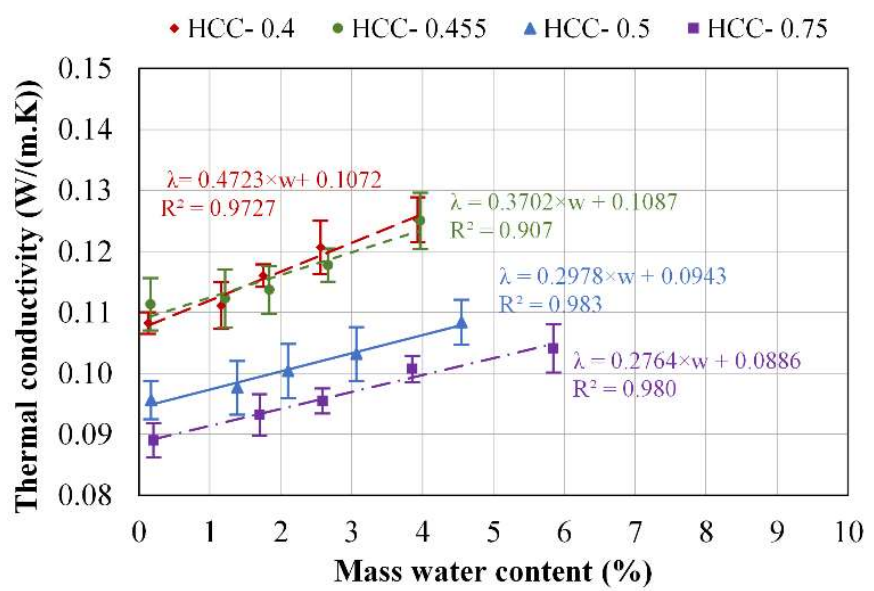

Fig. 22. Thermal conductivity of HCC versus mass water content.

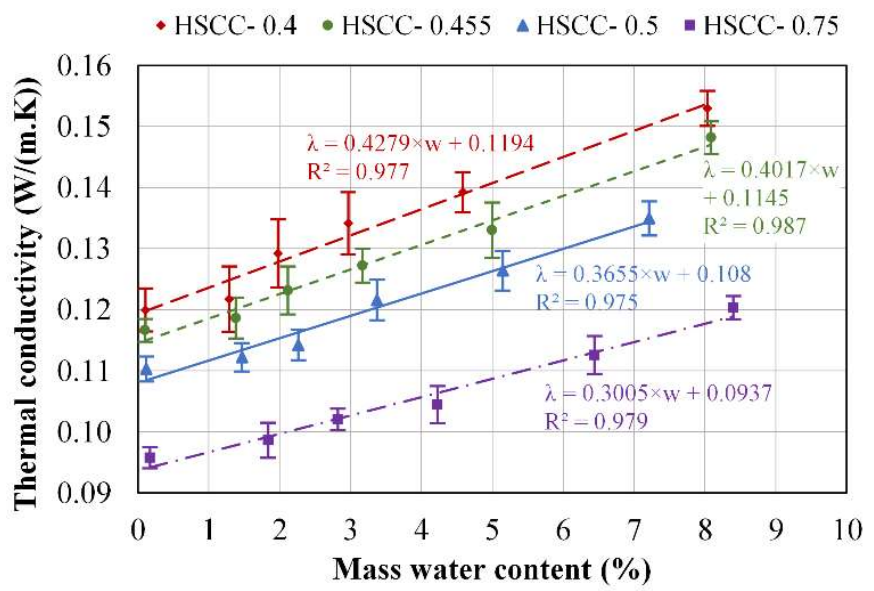

Fig. 23. Thermal conductivity of HSCC versus mass water content.

\subsubsection{SCS model for predicting thermal conductivity}

The self-consistent scheme is used to model the thermal conductivity of the solid phase $\lambda_{\mathrm{s}}$ with the two-phase model, from thermal conductivity values measured at dry state, skeleton density values and total porosity values obtained by the pycnometer method. Results are presented in Table 6 . 
deviation about $5 \%$. These values are in the range of values found in the literature. For hemp-lime concretes, the thermal conductivity values of the solid phase range from 0.612 to $0.791 \mathrm{~W} /(\mathrm{m} . \mathrm{K})$ depending on hemp to lime ratio in [10], and it is $0.63 \mathrm{~W} /(\mathrm{m} . \mathrm{K})$ in [67].

Table 6. Thermal conductivity values of designed materials $\lambda_{\text {exp }}$, solid particles $\lambda_{\mathrm{s}}$ at $23 \mathrm{C}$, according to the selfconsistent scheme.

\begin{tabular}{llccc}
\hline & $\begin{array}{c}\text { Hemp/Binder } \\
\text { ratio }\end{array}$ & $\mathrm{n}(\%)$ & $\begin{array}{c}\lambda_{\text {exp. }} \\
(\mathrm{W} /(\mathrm{m} . \mathrm{k}))\end{array}$ & $\begin{array}{c}\lambda_{\mathrm{s}} \\
(\mathrm{W} /(\mathrm{m} . \mathrm{k}))\end{array}$ \\
\hline \multirow{4}{*}{$\mathrm{HCC}$} & 0.4 & 76.1 & 0.108 & 0.491 \\
& 0.455 & 77.3 & 0.111 & 0.537 \\
& 0.5 & 78.2 & 0.096 & 0.460 \\
$\mathrm{H}$ & 0.75 & 81.1 & 0.089 & 0.484 \\
\hline & 0.4 & 73.1 & 0.120 & 0.494 \\
& 0.455 & 75.1 & 0.117 & 0.518 \\
& 0.5 & 77.2 & 0.110 & 0.527 \\
\hline
\end{tabular}

\subsubsection{Thermal conductivity as a function of water content}

Fig. 24 and Fig. 25 give the modelization with the three-phase self-consistent scheme (Eq. (8)) and the experimental data of the thermal conductivity versus the water content for the HCC and the HSCC composites respectively. Fig 27 and Fig 28 give the modelled values of thermal conductivity for the different hemp ratios and water contents versus the experimental data. In all cases, there is a good correlation between experimental data and self-consistent scheme. The self-consistent scheme leads to better results for HCC than for HSCC and better results for relative humidities up to $65 \% \mathrm{RH}$.

For all formulations and for relative humidities less than or equal to $65 \%$, the difference between experimental data and modelled values is less than $5 \%$. Above $65 \% \mathrm{RH}$, the deviation reaches $6.5 \%$ at $80 \%$ RH for HCC- 0.4 and HCC- $0.75,8.5 \%$ at $90 \%$ RH for HSCC- 0.455 and HSCC-0.5. It remains below 5\% for the other formulations. The deviations observed are correlated with lower modelled slopes than experimental ones (30$42 \%$ lower for HSCC formulations and 33-55\% lower for HCC formulations). 


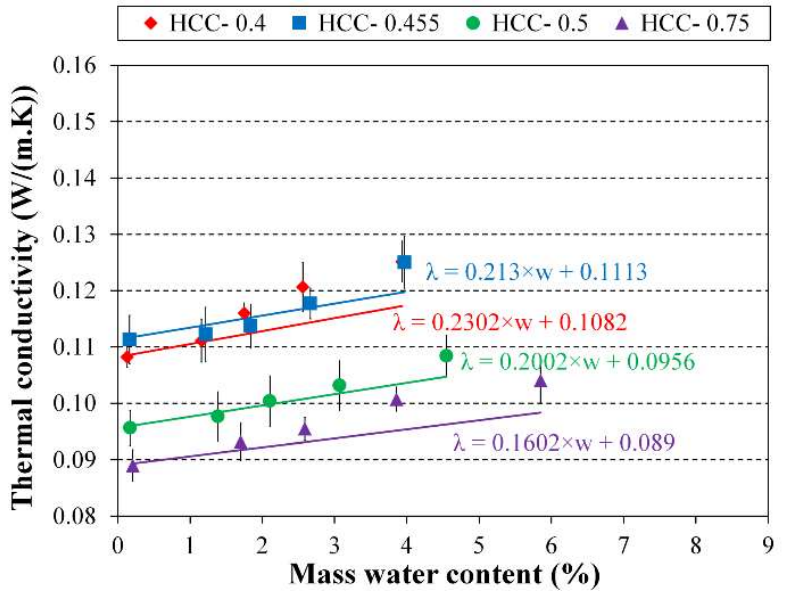

Fig. 24. Thermal conductivity of HCC versus mass water content - Points: experimental data; Lines: three phase self-consistent scheme model.

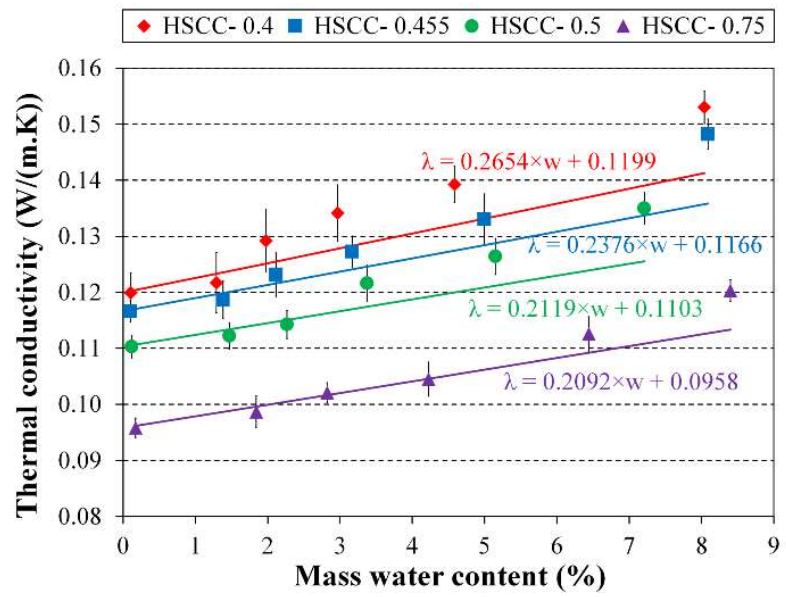

544 Fig. 25. Thermal conductivity of HSCC versus mass water content - Points: experimental data; Lines: three phase self-consistent scheme model. 


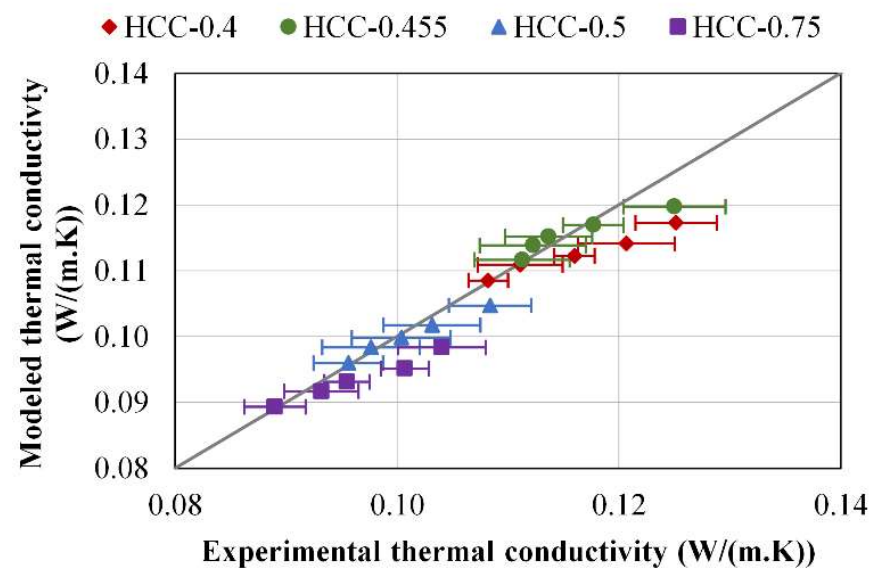

Fig. 26: Comparison between experimental and predicted values of thermal conductivity of HCC.

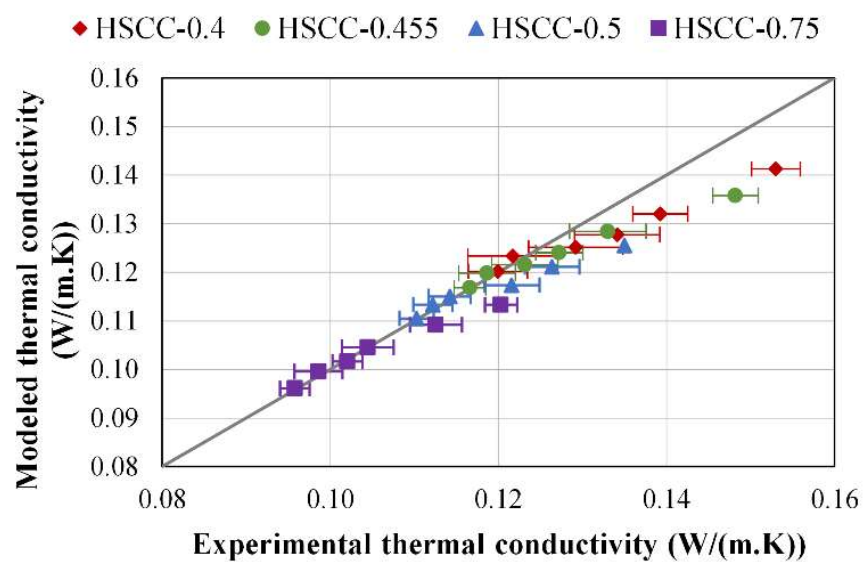

Fig. 27: Comparison between experimental and predicted values of thermal conductivity of HSCC.

\section{Conclusion}

This work investigates the use of clay as binder of hemp composite and it highlights the effect of clay stabilization and hemp to binder ratio on hygrothermal properties. than with unstabilized clay. The density values range from $347 \mathrm{~kg} / \mathrm{m}^{3}$ to $469 \mathrm{~kg} / \mathrm{m}^{3}$ for $\mathrm{HCC}$, and from 382 $\mathrm{kg} / \mathrm{m}^{3}$ to $523 \mathrm{~kg} / \mathrm{m}^{3}$ for HSCC. Analyzing the links between formulation and density, it appears that, the shiv particles in the mix are systematically associated to a void volume close to the particles volume. 
The designed composites are hygroscopic and breathable materials. Their sorption curves are sigmoid. For each kind of matrix, a linear correlation between hemp content and water content is identified. This allows to evaluate the contribution of hemp shiv and binder to the composite sorption. Then, it is possible to predict the sorption curve for such kind of matrix and implementation whatever the hemp to binder ratio is. The MBV values of all composites range from 2.07 to $2.33 \mathrm{~g} /\left(\mathrm{m}^{2} . \% \mathrm{RH}\right)$ so, these composites are excellent hygric regulators. The composites made with stabilized clay have a better MBV than the composites made with unstabilized clay.

The thermal conductivity values of the designed composites at dry state are between 0.089 and $0.120 \mathrm{~W} /(\mathrm{m} . \mathrm{K})$, making them suitable for use as distributed insulation. The study points out that the thermal conductivity mainly depends on the density. More, the thermal conductivity value increases with water content by up to $17 \%$ from dry state to wet state at $80 \% \mathrm{RH}$, with higher effect for lower hemp content.

Finally, the designed composites are promising materials to be used for building envelope. Actually, they can contribute to reduce energy needs of building and to ensure high hygrothermal comfort of users.

\section{References}

[1] S. Amziane, L. Arnaud, Bio-aggregate-based Building Materials, 1st ed., John Wiley \& Sons, Ltd, 2013. https://doi.org/10.1002/9781118576809.

[2] H.M.G. van der Werf, Life Cycle Analysis of field production of fibre hemp, the effect of production practices on environmental impacts, Euphytica. 140 (2004) 13-23. https://doi.org/10.1007/s10681-0044750-2.

[3] M.P. Boutin, C. Flamin, S. Quinton, G. Gosse, Etude des caractéristiques environnementales du chanvre par l'analyse de son cycle de vie, Ministère L'agriculture Pêche MAP. 4 (2006) B1.

[4] K. Ip, A. Miller, Life cycle greenhouse gas emissions of hemp-lime wall constructions in the UK, Resour. Conserv. Recycl. 69 (2012) 1-9. https://doi.org/10.1016/j.resconrec.2012.09.001.

[5] S. Pretot, F. Collet, C. Garnier, Life cycle assessment of a hemp concrete wall: Impact of thickness and coating, Build. Environ. 72 (2014) 223-231. https://doi.org/10.1016/j.buildenv.2013.11.010.

[6] F. Pittau, F. Krause, G. Lumia, G. Habert, Fast-growing bio-based materials as an opportunity for storing carbon in exterior walls, Build. Environ. 129 (2018) 117-129. https://doi.org/10.1016/j.buildenv.2017.12.006.

[7] M.P. Boutin, C. Flamin, S. Quinton, G. Gosse, Analyse du cycle de vie: Compounds thermoplastiques chargés fibres de chanvre et Mur en béton de chanvre banché sur ossature bois, Rapp. D'Etude INRA Lille Réf MAP 04 B1. 501 (2005) 32. 
[8] V. Cérézo, Propriétés mécaniques, thermiques et acoustiques d'un matériau à base de particules végétales : approche expérimentale et modélisation théorique, thesis, Lyon, INSA, 2005. http://www.theses.fr/2005ISAL0037 (accessed April 13, 2020).

[9] F. Collet, S. Pretot, Experimental investigation of moisture buffering capacity of sprayed hemp concrete, Constr. Build. Mater. 36 (2012) 58-65. https://doi.org/10.1016/j.conbuildmat.2012.04.139.

[10] F. Collet, S. Pretot, Thermal conductivity of hemp concretes: Variation with formulation, density and water content, Constr. Build. Mater. 65 (2014) 612-619. https://doi.org/10.1016/j.conbuildmat.2014.05.039.

[11] A. Evrard, Sorption behaviour of Lime-Hemp Concrete and its relation to indoor comfort and energy demand, in: Proc. 23rd Conf. Passive Low Energy Archit. Geneva Switz., 2006.

[12] A.D. Tran Le, C. Maalouf, T.H. Mai, E. Wurtz, F. Collet, Transient hygrothermal behaviour of a hemp concrete building envelope, Energy Build. 42 (2010) 1797-1806. https://doi.org/10.1016/j.enbuild.2010.05.016.

[13] F. Collet, S. Pretot, C. Lanos, Performance hydrique de bétons de chanvre: effet de l'enduit sur leur capacité de régulateurs hydriques, 31ème Rencontres AUGC ENS Cachan 2013. (2013) 1-10.

[14] L. Arnaud, E. Gourlay, Experimental study of parameters influencing mechanical properties of hemp concretes, Constr. Build. Mater. 28 (2012) 50-56. https://doi.org/10.1016/j.conbuildmat.2011.07.052.

[15] M. Rahim, O. Douzane, A.T. Le, G. Promis, B. Laidoudi, A. Crigny, B. Dupre, T. Langlet, Characterization of flax lime and hemp lime concretes: Hygric properties and moisture buffer capacity, Energy Build. 88 (2015) 91-99.

[16] M. Rahim, O. Douzane, A.D. Tran Le, G. Promis, T. Langlet, Characterization and comparison of hygric properties of rape straw concrete and hemp concrete, Constr. Build. Mater. 102 (2016) 679-687. https://doi.org/10.1016/j.conbuildmat.2015.11.021.

[17] F. Collet, Caractérisation hydrique et thermique de matériaux de génie civil à faibles impacts environnementaux, PhD-Thesis, Rennes, INSA, 2004. https://www.theses.fr/2004ISAR0016 (accessed July 15, 2020).

[18] J. Chamoin, Optimisation des propriétés (physiques, mécaniques et hydriques) de bétons de chanvre par la maîtrise de la formulation, phD-thesis, Rennes, INSA, 2013. https://www.theses.fr/2013ISAR0016 (accessed July 15, 2020).

[19] P. de Bruijn, P. Johansson, Moisture fixation and thermal properties of lime-hemp concrete, Constr. Build. Mater. 47 (2013) 1235-1242. https://doi.org/10.1016/j.conbuildmat.2013.06.006.

[20] F. Collet, J. Chamoin, S. Pretot, C. Lanos, Comparison of the hygric behaviour of three hemp concretes, Energy Build. 62 (2013) 294-303. https://doi.org/10.1016/j.enbuild.2013.03.010.

[21] R. Walker, S. Pavía, Moisture transfer and thermal properties of hemp-lime concretes, Constr. Build. Mater. 64 (2014) 270-276. https://doi.org/10.1016/j.conbuildmat.2014.04.081.

[22] S. Benfratello, C. Capitano, G. Peri, G. Rizzo, G. Scaccianoce, G. Sorrentino, Thermal and structural properties of a hemp-lime biocomposite, Constr. Build. Mater. 48 (2013) 745-754. https://doi.org/10.1016/j.conbuildmat.2013.07.096.

[23] A. Evrard, Transient hygrothermal behaviour of lime-hemp materials, Universite Catholique De Louvain, 2008 . 
[24] T.T. Nguyen, Contribution à l'étude de la formulation et du procédé de fabrication d'éléments de construction en béton de chanvre, phD-thesis, Université de Bretagne Sud, 2010. https://tel.archivesouvertes.fr/tel-01017510/document.

[25] C. Magniont, Contribution à la formulation et à la caractérisation d'un écomatériau de construction à base d'agroressources, phD-thesis, Toulouse 3, 2010. https://www.theses.fr/2010TOU30101 (accessed July 15, 2020).

[26] V. Nozahic, Vers une nouvelle démarche de conception des bétons de végétaux lignocellulosiques basée sur la compréhension et l'amélioration de l'interface liant / végétal : application à des granulats de chenevotte et de tige de tournesol associés à un liant ponce / chaux, phD-thesis, Clermont-Ferrand 2, 2012. https://www.theses.fr/2012CLF22265 (accessed July 15, 2020).

[27] T.M. Dinh, Contribution au développement de béton de chanvre préfabriqué utilisant un liant pouzzolanique innovant, phD-thesis, Toulouse 3, 2014. http://www.theses.fr/2014TOU30078 (accessed July 15,2020$)$.

[28] R. Busbridge, Hemp-Clay: an initial investigation into the thermal, structural and environmental credentials of monolithic clay and hemp walls, Cent. Altern. Technol. UK Sch. Comput. Technol. Univ. East Lond. UK. (2009).

[29] H. Cagnon, J.E. Aubert, M. Coutand, C. Magniont, Hygrothermal properties of earth bricks, Energy Build. 80 (2014) 208-217. https://doi.org/10.1016/j.enbuild.2014.05.024.

[30] D. Allinson, M. Hall, Hygrothermal analysis of a stabilised rammed earth test building in the UK, Energy Build. 42 (2010) 845-852. https://doi.org/10.1016/j.enbuild.2009.12.005.

[31] Y. Millogo, J.-C. Morel, J.-E. Aubert, K. Ghavami, Experimental analysis of Pressed Adobe Blocks reinforced with Hibiscus cannabinus fibers, Constr. Build. Mater. 52 (2014) 71-78. https://doi.org/10.1016/j.conbuildmat.2013.10.094.

[32] Y. Millogo, J.-E. Aubert, E. Hamard, J.-C. Morel, How Properties of Kenaf Fibers from Burkina Faso Contribute to the Reinforcement of Earth Blocks, Materials. 8 (2015) 2332-2345. https://doi.org/10.3390/ma8052332.

[33] T. Ashour, H. Georg, W. Wu, An experimental investigation on equilibrium moisture content of earth plaster with natural reinforcement fibres for straw bale buildings, Appl. Therm. Eng. 31 (2011) 293-303. https://doi.org/10.1016/j.applthermaleng.2010.09.009.

[34] A. Bouguerra, A. Ledhem, F. de Barquin, R.M. Dheilly, M. Quéneudec, Effect of microstructure on the mechanical and thermal properties of lightweight concrete prepared from clay, cement, and wood aggregates, Cem. Concr. Res. 28 (1998) 1179-1190. https://doi.org/10.1016/S0008-8846(98)00075-1.

[35] Faria Paulina, Santos Tânia, Aubert Jean-Emmanuel, Experimental Characterization of an Earth EcoEfficient Plastering Mortar, J. Mater. Civ. Eng. 28 (2016) 04015085. https://doi.org/10.1061/(ASCE)MT.1943-5533.0001363.

[36] J. Pinto, A. Paiva, H. Varum, A. Costa, D. Cruz, S. Pereira, L. Fernandes, P. Tavares, J. Agarwal, Corn's cob as a potential ecological thermal insulation material, Energy Build. 43 (2011) 1985-1990. https://doi.org/10.1016/j.enbuild.2011.04.004.

[37] H. Bal, Y. Jannot, N. Quenette, A. Chenu, S. Gaye, Water content dependence of the porosity, density and thermal capacity of laterite based bricks with millet waste additive, Constr. Build. Mater. 31 (2012) 144150. https://doi.org/10.1016/j.conbuildmat.2011.12.063. 
[38] P. Meukam, A. Noumowe, Y. Jannot, R. Duval, Caractérisation thermophysique et mécanique de briques de terre stabilisées en vue de l'isolation thermique de bâtiment, Mater. Struct. 36 (2003) 453-460. https://doi.org/10.1007/BF02481525.

[39] J. Khedari, P. Watsanasathaporn, J. Hirunlabh, Development of fibre-based soil-cement block with low thermal conductivity, Cem. Concr. Compos. 27 (2005) 111-116. https://doi.org/10.1016/j.cemconcomp.2004.02.042.

[40] M. Maddison, T. Mauring, K. Kirsimäe, Ü. Mander, The humidity buffer capacity of clay-sand plaster filled with phytomass from treatment wetlands, Build. Environ. 44 (2009) 1864-1868. https://doi.org/10.1016/j.buildenv.2008.12.008.

[41] M. Labat, C. Magniont, N. Oudhof, J.-E. Aubert, From the experimental characterization of the hygrothermal properties of straw-clay mixtures to the numerical assessment of their buffering potential, Build. Environ. 97 (2016) 69-81. https://doi.org/10.1016/j.buildenv.2015.12.004.

[42] S. Goodhew, R. Griffiths, Sustainable earth walls to meet the building regulations, Energy Build. 37 (2005) 451-459. https://doi.org/10.1016/j.enbuild.2004.08.005.

[43] I. Niang, C. Maalouf, T. Moussa, C. Bliard, E. Samin, C. Thomachot-Schneider, M. Lachi, H. Pron, T.H. Mai, S. Gaye, Hygrothermal performance of various Typha-clay composite, J. Build. Phys. 42 (2018) 316-335.

[44] Y. Brouard, N. Belayachi, D. Hoxha, N. Ranganathan, S. Méo, Mechanical and hygrothermal behavior of clay - Sunflower (Helianthus annuus) and rape straw (Brassica napus) plaster bio-composites for building insulation, Constr. Build. Mater. 161 (2018) 196-207. https://doi.org/10.1016/j.conbuildmat.2017.11.140.

[45] R. Busbridge, R. Rhydwen, AN INVESTIGATION OF THE THERMAL PROPERTIES OF HEMP AND CLAY MONOLITHIC WALLS, (2010) 10.

[46] T. Vinceslas, T. Colinart, E. Hamard, A.H. de Ménibus, T. Lecompte, H. Lenormand, Light Earth Performances For Thermal Insulation: Application To Earth-Hemp, in: B.V.V. Reddy, M. Mani, P. Walker (Eds.), Earthen Dwell. Struct., Springer Singapore, Singapore, 2019: pp. 357-367. https://doi.org/10.1007/978-981-13-5883-8_31.

[47] K. Al Rim, A. Ledhem, O. Douzane, R.M. Dheilly, M. Queneudec, Influence of the proportion of wood on the thermal and mechanical performances of clay-cement-wood composites, Cem. Concr. Compos. 21 (1999) 269-276. https://doi.org/10.1016/S0958-9465(99)00008-6.

[48] T. Ashour, H. Wieland, H. Georg, F.-J. Bockisch, W. Wu, The influence of natural reinforcement fibres on insulation values of earth plaster for straw bale buildings, Mater. Des. 31 (2010) 4676-4685. https://doi.org/10.1016/j.matdes.2010.05.026.

[49] A. Ledhem, R.M. Dheilly, M.L. Benmalek, M. Quéneudec, Properties of wood-based composites formulated with aggregate industry waste, Constr. Build. Mater. 14 (2000) 341-350. https://doi.org/10.1016/S0950-0618(00)00037-4.

[50] A. Bouguerra, A. Aït-Mokhtar, O. Amiri, M.B. Diop, Measurement of thermal conductivity, thermal diffusivity and heat capacity of highly porous building materials using transient plane source technique, Int. Commun. Heat Mass Transf. 28 (2001) 1065-1078. https://doi.org/10.1016/S0735-1933(01)00310-4.

[51] P. Meukam, Y. Jannot, A. Noumowe, T.C. Kofane, Thermo physical characteristics of economical building materials, Constr. Build. Mater. 18 (2004) 437-443. https://doi.org/10.1016/j.conbuildmat.2004.03.010. 
[52] H.-R. Kymäläinen, A.-M. Sjöberg, Flax and hemp fibres as raw materials for thermal insulations, Build. Environ. 43 (2008) 1261-1269. https://doi.org/10.1016/j.buildenv.2007.03.006.

[53] B. Mazhoud, F. Collet, S. Pretot, C. Lanos, Mechanical properties of hemp-clay and hemp stabilized clay composites, Constr. Build. Mater. 155 (2017) 1126-1137. https://doi.org/10.1016/j.conbuildmat.2017.08.121.

[54] S. Amziane, F. Collet, eds., Bio-aggregates Based Building Materials : State-of-the-Art Report of the RILEM Technical Committee 236-BBM, Springer Netherlands, 2017. https://doi.org/10.1007/978-94-024$1031-0$

[55] D. ASTM, Standard test methods for specific gravity of soil solids by water pycnometer, D854. (2010).

[56] K.S. Sing, Reporting physisorption data for gas/solid systems with special reference to the determination of surface area and porosity (Recommendations 1984), Pure Appl. Chem. 57 (1985) 603-619.

[57] S. Brunauer, P.H. Emmett, E. Teller, Adsorption of gases in multimolecular layers, J. Am. Chem. Soc. 60 (1938) 309-319.

[58] E.P. Barrett, L.G. Joyner, P.P. Halenda, The determination of pore volume and area distributions in porous substances. I. Computations from nitrogen isotherms, J. Am. Chem. Soc. 73 (1951) 373-380.

[59] E.A. Guggenheim, Applications of statistical mechanics, CERN Doc. Serv. (1966). https://cds.cern.ch/record/231343 (accessed April 14, 2020).

[60] R.B. Anderson, Modifications of the Brunauer, Emmett and Teller Equation1, J. Am. Chem. Soc. 68 (1946) 686-691. https://doi.org/10.1021/ja01208a049.

[61] R.B. Anderson, W.K. Hall, Modifications of the Brunauer, Emmett and Teller Equation II1, J. Am. Chem. Soc. 70 (1948) 1727-1734. https://doi.org/10.1021/ja01185a017.

[62] J.H. Boer, dynamical character of adsorption, (1968). http://agris.fao.org/agrissearch/search.do?recordID=US201300593799 (accessed April 14, 2020).

[63] M.T. van Genuchten, A Closed-form Equation for Predicting the Hydraulic Conductivity of Unsaturated Soils, Soil Sci. Soc. Am. J. 44 (1980) 892-898. https://doi.org/10.2136/sssaj1980.03615995004400050002x.

[64] C. Rode, R. Reuhkuri, B. Time, A. Gustavsan, T. Ojanen, J. Ahonen, K. Svennberg, Moisture Buffering of Building Materials, Report BYG-DTU R-126, Rep. Nord. Innov. Cent. Dep. Civ. Eng. Tech. Univ. Den. (2005).

[65] J. Hladik, Métrologie des propriétés thermophysiques des matériaux, (1990).

[66] A. Bourdot, T. Moussa, A. Gacoin, C. Maalouf, P. Vazquez, C. Thomachot-Schneider, C. Bliard, A. Merabtine, M. Lachi, O. Douzane, H. Karaky, G. Polidori, Characterization of a hemp-based agromaterial: Influence of starch ratio and hemp shive size on physical, mechanical, and hygrothermal properties, Energy Build. 153 (2017) 501-512. https://doi.org/10.1016/j.enbuild.2017.08.022.

[67] M. Rahim, O. Douzane, A.D. Tran Le, T. Langlet, Effect of moisture and temperature on thermal properties of three bio-based materials, Constr. Build. Mater. 111 (2016) 119-127. https://doi.org/10.1016/j.conbuildmat.2016.02.061.

[68] L. Arnaud, H. Monnet, C. Cordier, F. Sallet, Modélisation par homogénéisation autocohérente de la conductivité thermique de bétons et laines de chanvre, in: Colloq. Annu. - SFT, 2000: pp. 543-548. 
http://pascal-francis.inist.fr/vibad/index.php?action=getRecordDetail\&idt=1019103 (accessed February 1, 2021).

[69] T. Ashour, A. Korjenic, S. Korjenic, Equilibrium moisture content of earth bricks biocomposites stabilized with cement and gypsum, Cem. Concr. Compos. 59 (2015) 18-25. https://doi.org/10.1016/j.cemconcomp.2015.03.005.

[78] D. Taoukil, A. El bouardi, F. Sick, A. Mimet, H. Ezbakhe, T. Ajzoul, Moisture content influence on the thermal conductivity and diffusivity of wood-concrete composite, Constr. Build. Mater. 48 (2013) 104115. https://doi.org/10.1016/j.conbuildmat.2013.06.067.

[70] A. Bouguerra, H. Sallée, F. de Barquin, R.M. Dheilly, M. Quéneudec, Isothermal moisture properties of wood-cementitious composites, Cem. Concr. Res. 29 (1999) 339-347. https://doi.org/10.1016/S00088846(98)00232-4.

[71] D. Samri, Analyse physique et caractérisation hygrothermique des matériaux de construction : approche expérimentale et modélisation numérique, 2008.

[72] F. Collet, S. Pretot, B. Mazhoud, L. Bessette, C. Lanos, Comparing hemp composites made with mineral or organic binder on thermal, hygric and mechanical point of view, in: Proc. First Int. Conf. Bio-Based Build. Mater. ICBBM, 2015.

[73] T. Le, A. Dung, Etude des transferts hygrothermiques dans le béton de chanvre et leur application au bâtiment, phD-thesis, Reims, 2010.

[74] F. Collet, S. Prétot, C. Lanos, Hemp-straw composites: thermal and hygric performances, Energy Procedia. 139 (2017) 294-300.

[75] R. Haik, G. Bar-Nes, A. Peled, I.A. Meir, Alternative unfired binders as lime replacement in hemp concrete, Constr. Build. Mater. 241 (2020) 117981. https://doi.org/10.1016/j.conbuildmat.2019.117981.

[76] E. Agoua, E. Allognon-Houessou, E. Adjovi, B. Togbedji, Thermal conductivity of composites made of wastes of wood and expanded polystyrene, Constr. Build. Mater. 41 (2013) 557-562. https://doi.org/10.1016/j.conbuildmat.2012.12.016.

[77] M. Bederina, L. Marmoret, K. Mezreb, M.M. Khenfer, A. Bali, M. Quéneudec, Effect of the addition of wood shavings on thermal conductivity of sand concretes: Experimental study and modelling, Constr. Build. Mater. 21 (2007) 662-668. https://doi.org/10.1016/j.conbuildmat.2005.12.008. 